\title{
Relative Concerns of Rural-to-Urban Migrants in China*
}

\author{
Alpaslan Akay, Olivier Bargain, Klaus F. Zimmermann
}

January 2011

\begin{abstract}
As their environment changes, migrants constitute an interesting group to study the effect of relative income on subjective well-being. This paper focuses on the huge population of rural-to-urban migrants in China. Using a novel dataset, we find that the well-being of migrants depends on several reference groups: it is negatively affected by the income of other migrants and workers of home regions; in contrast, we identify a positive, 'signal' effect vis-à-vis urban workers: larger urban incomes indicate higher income prospects for the migrants. These effects are particularly strong for migrants who wish to settle permanently, decline with years since migrations and change with other characteristics including work conditions and community ties.
\end{abstract}

Key Words : China, relative concerns, well-being.

JEL Classification : C90, D63

${ }^{*}$ Acknowledgement: Akay is affiliated to IZA and the University of Gothenburg, Bargain is affiliated to University College Dublin and IZA, Zimmermann is affiliated to IZA, Bonn University and DIW Berlin. We are grateful to Yang Yumei for the very efficient research assistance, and to discussants and participants at the World Bank "German Development Day", the 2nd CIER/IZA Annual Workshop and various seminars. Collection of the RUMICI data used in this paper is financed by IZA, ARC/AusAid, the Ford Foundation, and the Ministry of Labor and Social Security of China. Corresponding author: A. Akay, IZA, Box 7240, 53072 Bonn, Germany; e-mail: akay@iza.org; tel.: +49 2283894508. 


\section{Introduction}

It is well-known today that well-being depends not only on absolute income but also on the income relative to others. The issue of relative concerns was already discussed by Adam Smith, Karl Marx and several scholars in the past (Veblen, 1899, Duesenberry, 1949) and has been revisited in the recent literature on self-reported subjective well-being (e.g., Clark and Oswald, 1996; McBride, 2001; Ferrer-i-Carbonell, 2005; Luttmer, 2005; Senik, 2004, 2008; Pérez-Asenjo, 2010; see also the survey of Clark et al., 2008) or tailor-made survey experiments (e.g., Solnick and Hemenway 1998; Johansson-Stenman et al., 2002; Alpizar et al., 2005). In surveys where people are asked about their level of well-being, it is intuitive to think that they form an answer after evaluating their position relative to the income of others. The income of a reference group may negatively affect subjective well-being (SWB) if people feel relatively deprived: this so-called 'status effect', reflecting envy and jealousy, generally prevails in empirical studies on developed countries. ${ }^{1}$ The more limited literature about relative concerns in developing and transition economies shows more mixed results. ${ }^{2}$ A positive relative concern is sometimes reported and can be interpreted as a sign of tight community ties and altruistic preferences among poor rural households (see Kingdon and Knight, 2007, and Bookwalter and Dalenberg, 2010, for South Africa). Alternatively, it may reveal a 'signal effect' (or 'tunnel effect', in the sense of Hirchmann, 1973), i.e., a worker's well-being is positively affected by the observation of other people's faster income progression if he interprets this movement as a sign that his own turn will come around soon. Opposite effects, envy (status effects) and ambition (signal effect), may offset each other, and their relative weight depends in particular on beliefs about social mobility, as extensively discussed by Senik (2008).

A crucial aspect in this literature is the notion of the reference group. It is certainly difficult to identify the relevant group for a given population or to understand how comparisons are formed and evolve over time or with individual aspirations and economic circumstances. The literature has suggested different orbits of comparison based on spatial proximity and other dimensions (see McBride, 2001; Clark and Oswald, 1996;

\footnotetext{
${ }^{1}$ A negative effect of relative income on SWB is found almost systematically in a series of papers: Clark and Oswald (1996); McBride (2001); Ferrer-i-Carbonell (2005); Luttmer (2005); Senik (2004, 2008). See also the enlightening survey Clark et al., (2008).

${ }^{2}$ See Graham and Pettinato (2002) on Peru and Russia; Kingdon and Knight $(2006,2007)$ and Bookwalter and Dalenberg (2010) on South Africa; Akay and Martinsson (2010) on Ethiopia; and Ravallion and Lokshin (2001, 2002) on Russia; see Graham (2005) for a helpful overview. There is a particularly burgeoning literature on China: Appleton and Song (2009) and Gao and Smyth (2010) specifically study SWB in urban regions; Knight et al. (2009) focus on rural China; Knight and Gunatilaka (2010b) study the rural-urban divide.
} 
Ferrer-i-Carbonell, 2005). ${ }^{3}$ In this context, internal migrants offer an interesting case study. Migrant workers are indeed placed in different geographical, social and economic environments. Confronted with different types of populations and different set of opportunities, they may refer to several potential reference groups including those "left behind", other migrants and natives. In this paper we investigate this question by focusing on rural-to-urban migrants in China. Chinese internal migration is a unique experience in human history and may well be one of the greatest migration events ever to have taken place (Cai et al., 2008). As a result, the welfare of this population is worth taking as a subject of investigation. Moreover, we dispose of a novel dataset that is appropriate to check whether potential comparison groups statistically affect migrants' well-being. The migrant-specific section of the dataset, collected in 2008, was designed to provide a fresh and representative picture of migrants in China. Compared to previous surveys, it is not limited to a geographically restricted sample but covers the main emigration provinces and immigration cities in China, and all types of rural-to-urban migrants. Most interestingly, the dataset also contains samples of urban households, surveyed in the same cities as migrants (the main immigration destinations in China), and of rural workers mainly located in provinces from where observed migrants originate. Establishing these links allows us to test the impact of different comparison groups on migrant SWB in a systematic and comprehensive manner. To address the high degree of heterogeneity among migrants, we combine this evidence with a time dimension, i.e., investigate how relative concerns change with the time since first migration, with information about the desired duration of stay and with many other characteristics related to family background, work conditions and social networks.

Another paper has recently studied internal migration and SWB in China (Knight and Gunatilaka, 2010a). The authors focus specifically on the welfare gap between migrants and urban and rural people. Despite migrants moving to cities in search of a better life, they may have false expectations about their future achievement or be confronted with a change in aspirations as their reference group changes. The authors provide interesting evidence along these lines, but neither this paper nor the limited literature on SWB in transition economies provides a systematic examination of the role of different, potential reference groups, as suggested here.

Our results can be summarized as follows. A first exploratory analysis of the determinants of SWB aims at testing alternative reference groups for each population (rural workers, migrants and urban workers) separately. While there is some evidence that rural

\footnotetext{
${ }^{3}$ We are aware of only three studies in which people are asked directly to whom they compare themselves: Clark and Senik (2010), Senik (2009) and Knight et al. (2009).
} 
people have positive relative concerns toward other rural, urban residents and migrants seem to behave more closely to the pattern found in developed countries, i.e., they experience a strong status effect when comparing themselves to other urban/migrants. Then, our main analysis focuses specifically on migrants' relative concerns and examines the role of different, possibly simultaneous, reference groups. Results indicate negative relative concerns toward other migrants and rural workers of home regions, i.e., a status effect. In contrast, we find a positive and highly significant relative income effect vis-à-vis the urban reference group. After ruling out altruism or externalities as possible explanations, we suggest a 'signal effect' interpretation for the latter effect: more successful urban natives indicate higher chances of prosperity for migrants in the future. Finally, we decrease the degree of heterogeneity within the migrant population by sorting migrants according to the duration of stay, expectations to return to home regions and other characteristics linked to family circumstances, assimilation skills and job prospects. In particular, the desire to stay in the urban region, and hence forming or leaving a reference group, has a noticeable impact on our results. Migrants who wish to settle permanently in urban regions show the strongest status effect. Yet this decreases over years since migration, reflecting a possible switch in reference groups or selection among workers who aim to stay. The status effect toward other migrants becomes weaker when the reference group comprises migrants of the same source region, which conveys community ties play a role in urban regions as well.

The remaining part of the paper is organized as follows. Section 2 describes the historical background on Chinese migration, the data used and the empirical approach. Results are reported and discussed in Section 3, first comparing relative concerns of rural, urban and migrants, then focusing specifically on migrants. We conclude with Section 4.

\section{Background, Data and Methodoloy}

\subsection{Background on Chinese Rural-to-Urban Migration}

The first stage of Chinese internal migration started after that the Chinese Communist Party came to power in 1949. Up until 1957, the rural labor force was allowed to migrate freely from rural to urban areas. In this period, the number of employees in urban areas, as a result of migration rose from 5.1 to 23.2 million employees, most of them coming from rural regions. During the "Great Leap Forward", in 1958 to 1960, the population of migrant workers increased quickly and the urban labor force reached around 29 million. However, owing to serious energy and resource allocation deficiencies, a large number of migrant workers returned to their rural hometowns during 1961 to 1963. Restrictions on 
rural-to-urban migration were implemented with the hukou system (Household Registration System), whereby the government strictly controlled the internal transfer of labor. As a result, only a small population of rural workers was able to move to urban areas during 1964 to 1978. Economic reforms implemented in China after 1978 increased the agricultural outcomes, and during the following decade many township enterprises developed and became the main source of employment for rural workers. Some migrant workers even returned to agriculture between 1989 and 1991. After Deng's Southern Tour Speech, in 1992, the Chinese economy and, in particular, highly labor-intensive industrial sectors developed rapidly, leading to high labor demand. In addition, modern agricultural practices have reduced the need for a large agricultural labor, and as early as 1994, it was estimated that China had a surplus of approximately 200 million agricultural workers. These factors, together with a growing inequality in living standards between rural and urban regions and changes in the hukou regulation, contributed to a dramatic acceleration of rural-to-urban migration witnessed in the past two decades. The total migrant labor force employed in secondary and tertiary industries was estimated to be 230 million in 2009, including 145 million workers who migrated from their home province, 30 million of whom left with their entire family. ${ }^{4}$.

\subsection{Data and Selection}

The empirical analysis in this paper uses the Rural to Urban Migration in China and Indonesia (RUMICI) dataset drawn from a novel survey covering rural and urban regions of China. It gathers a wealth of information on rural, urban and migrant households and is probably the most representative survey on urban and migrant households in China (see a detailed description and some applications in Meng et al., 2010). Previous surveys also contained SWB information notably the 2002 Chinese Household Income Project (CHIP2002 data) used for instance by Appleton and Song (2009). Yet the official sampling frame of the CHIP largely excluded those without urban hukou registration and particularly most of the "floating population" of rural-urban migrants. For this reason, another survey was specifically collected to gather information on migrant neighborhoods in some of the selected cities of the CHIP for the year 2002. However, it covered only five provinces (see Knight and Gunatilaka, 2010a; Gustaffson et al., 2008; Qu and Zhao, 2011, for an extensive comparison between RUMICI and this previous migrant survey).

The RUMICI dataset has benefited from these previous experiences. ${ }^{5}$ The survey cov-

\footnotetext{
${ }^{4}$ National Bureau of Statistics of China (2009): see www.stats.gov.cn/tjfx/fxbg/t20100319_402628281.htm.

${ }^{5}$ The consortium (see acknowledgements) piloting this survey includes some of the aforementioned authors involved in the previous 2002 migrant survey. The questionnaire of the RUMICI survey is partly
} 
ers the 10 largest provinces sending and receiving migrants (Shanghai, Jiangsu, Zhejiang, Hubei, Sichuan, Guangdong, Henan, Anhui, Sichuan and Hebei), and migrants were randomly chosen from the 15 top immigration destinations (cities) in China. ${ }^{6}$ It provides an accurate representation of the migrant population, including long-term migrants and temporary workers. In this paper we use the first wave, for 2008, which covers 18, 000 Chinese households. The dataset is composed of three distinct samples: "rural", "urban" and "migrant". All three samples gather information on household and personal characteristics, detailed health-status, employment, income, training and education of adults and children, social networks, family and social relationships, life events, mental health measures of the individuals and, for migrants, information related to migration history. In the survey a migrant is defined as an individual who is registered in a rural area (rural hukou) but lived in an urban region in 2008. The urban sample contains households who have lived in the urban regions for generations and can be treated as "natives" compared to rural-to-urban migrants.

This paper considers the direct and relative effect of individual labor income on SWB. Hence, we select workers aged between 16 and 70 who are the head of a household. The unemployed are not included, as they represent a small proportion of our sample and form the main stock of return migration (Bai and Song, 2002). More importantly, we aim to focus on labor income rather than overall standard of living. Examining personal labor income captures other dimensions likely to affect well-being, including a worker's success in the labor market in relation to own expectations and achievement. As explained below, we aim to test the relevance of reference income defined as the income of one's professional peers (see also Senik, 2008). After eliminating some households due to missing information, we obtain a sample of 2,180 rural workers, 1,863 urban workers and 4,879 migrants. The distribution of selected workers by type and across different provinces is reported in Table 1. All provinces contain the three types with two exceptions: the 9th province, Hebei, is a purely rural province in our data, and there are no rural samples for the 6th province, Shanghai. The important aspect of the data is that (i) migrants are sampled in the same cities as urban households; (ii) a majority of rural households

based on that of the 2002 survey. Unfortunately, the new dataset does not contain direct questions about reference groups (as used in Knight et al., 2009).

${ }^{6}$ The various definitions of reference groups used in this paper are primarily based on geographical proximity or origin. Hence, the boundaries of provinces and districts/cities, the two main entities used, are important. Provinces are defined according to official administrative boundaries. A smaller geographical entity is referred to as a "district" hereafter. For urban and migrant workers it is close to the notion of "city" but is based on the density of economic activity and workplaces - hence, it is somewhat smaller than the administrative boundaries of Chinese cities. Rural populations in the data are located in regions beyond the survey boundaries of the city where only rural people live. 
are located in provinces where migrants are coming from. On that second point, the last column of Table 1 reports the number of migrants by province of origin. A total of 4,536 migrant household heads are identified as having migrated from the same provinces as our rural sample, whilst 732 have come from other provinces.

Table 1: Distribution of Workers by Type and Across Chinese Provinces

\begin{tabular}{|c|c|c|c|c|c|c|c|c|c|}
\hline \multirow{2}{*}{$\begin{array}{l}\text { Province } \\
\text { Henan }\end{array}$} & & \multicolumn{2}{|c|}{ Urban } & \multicolumn{2}{|c|}{ Rural } & \multicolumn{2}{|c|}{ Migrants } & \multirow{2}{*}{$\begin{array}{c}\text { Total } \\
1050\end{array}$} & \multirow{2}{*}{$\begin{array}{c}\begin{array}{c}\text { Migrants' } \\
\text { province of } \\
\text { origin }\end{array} \\
742\end{array}$} \\
\hline & 1 & 205 & $23 \%$ & 302 & $34 \%$ & 543 & $43 \%$ & & \\
\hline Jiangsu & 2 & 243 & $20 \%$ & 385 & $41 \%$ & 577 & $39 \%$ & 1205 & 533 \\
\hline Sinhuan & 3 & 221 & $26 \%$ & 232 & $34 \%$ & 384 & $40 \%$ & 837 & 585 \\
\hline Hubei & 4 & 116 & $19 \%$ & 156 & $32 \%$ & 391 & $49 \%$ & 663 & 487 \\
\hline Anhui & 5 & 225 & $24 \%$ & 204 & $31 \%$ & 536 & $45 \%$ & 965 & 872 \\
\hline Shanghai & 6 & 237 & $36 \%$ & 0 & $0 \%$ & 493 & $64 \%$ & 730 & 2 \\
\hline Zhejiang & 7 & 243 & $23 \%$ & 490 & $38 \%$ & 567 & $40 \%$ & 1300 & 190 \\
\hline Guangdong & 8 & 251 & $21 \%$ & 222 & $17 \%$ & 992 & $62 \%$ & 1465 & 343 \\
\hline Hebei & 9 & 0 & $0 \%$ & 101 & $100 \%$ & 0 & $0 \%$ & 101 & 27 \\
\hline Chongqing & 10 & 122 & $22 \%$ & 88 & $18 \%$ & 395 & $60 \%$ & 605 & 23 \\
\hline \multirow[t]{2}{*}{ Others } & & & & & & & & & 732 \\
\hline & & 1,863 & & 2,180 & & 4,878 & & 8,921 & 4,536 \\
\hline
\end{tabular}

\subsection{Measure of Well-Being and Descriptive Statistics}

Following the literature, we sum up the answers to 12 questions of the General Health Questionnaire to construct the GHQ-12 measure of mental health. Each GHQ question, as reported in Appendix A, is coded from 1 to 4. Hence, the lowest score is 12 and the highest is 48. Following usual practice, we reverse the scale so that the higher scores indicate higher well-being and classify the measure into seven ordinal categories to be able to handle low and empty cells in the original index. GHQ-12 is one of the widely used SWB measures in economics and psychology (e.g., Clark and Oswald, 1994, 2002). It is closer to being medically conventional than direct questions about "life satisfaction" or "happiness" but is highly correlated with a direct report of overall life satisfaction or happiness. ${ }^{7}$ Following the literature, we interpret this measure as a proxy for the latent (experienced) individual utility (Kahneman and Sugden, 2005; van Praag et al., 2003; Clark et al., 2008).

\footnotetext{
${ }^{7}$ In our case, the happiness question (last in GHQ questions reported in Appendix A) could not be used anyway as it is based on a 1-4 scale and hence provides too little variation for our purpose.
} 

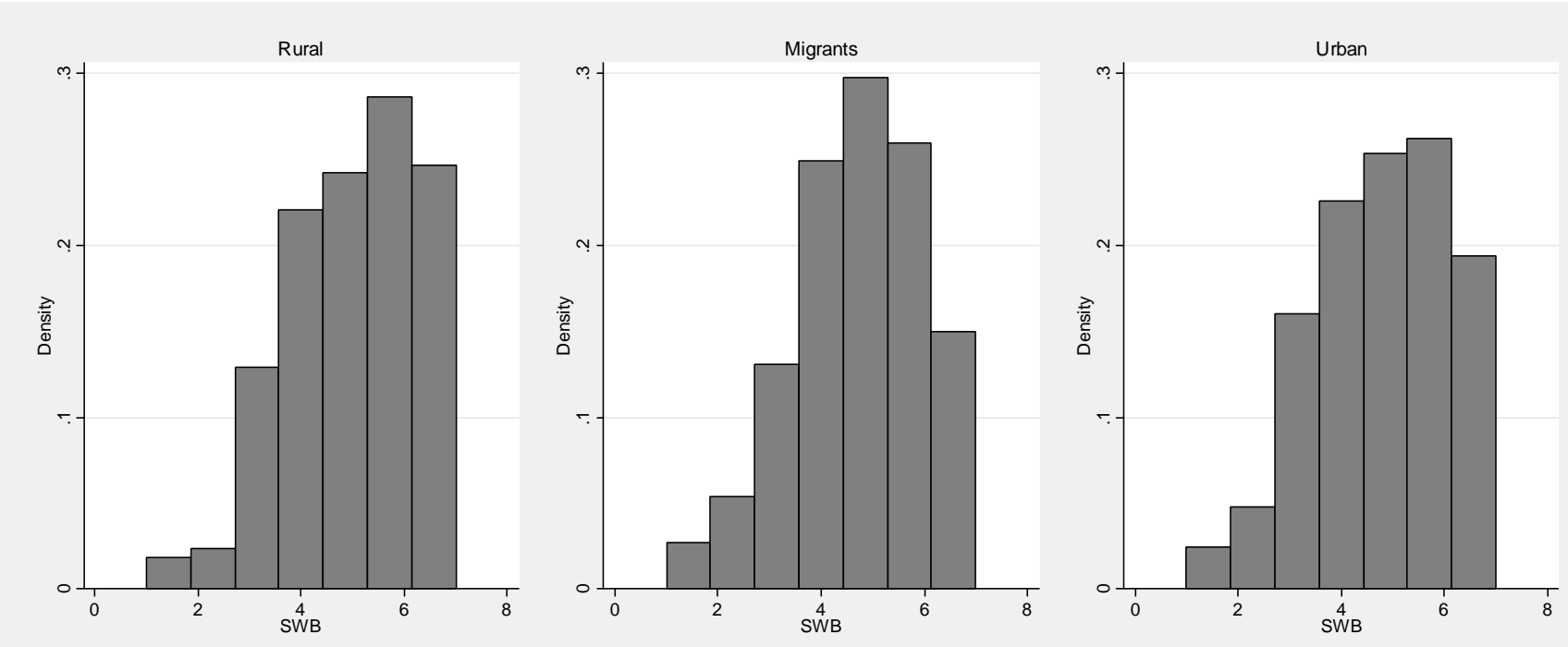

Note: Subjective Well-Being (SWB) is based on the GHQ-12 measure obtained by summing up 12 questions and categorized into 7 ordered values.

Figure 1: Distribution of Subjective Well-Being (GHQ-12) by Type of Worker

The distributions of SWB for rural, migrant and urban household heads in our selected sample are reported in Figure 1. The overall shapes are similar to the patterns usually reported in previous studies (e.g., Winkelmann and Winkelmann, 1998, for Germany; Clark and Oswald, 1994, for the UK). The distribution of SWB is left-skewed, with very few people reporting extreme low levels of well-being. Mean levels of SWB are 5.1 for rural (standard deviation of 1.5), 4.8 for migrants (1.5) and 4.9 for urban workers (1.5). That migrants achieved lower scores has already been studied by Knight and Gunatilaka (2010a), but notice here that differences in average SWB between the three types of workers are not significant.

Descriptive statistics are reported in Appendix Table B.1. It shows key explanatory variables used in the SWB estimations and common to the three types of workers: age, gender, marital status, being a salary worker, logarithm of worked hours, dummies for the number of children at home, health status, years of education, (absolute) labor income and dummies for social security coverage. We distinguish mean values for different levels of SWB (1-3, 4-5 and 6-7). Around $80 \%$ of the migrants are salaried workers, which is larger than for rural workers, more often self-employed, but lower than for urban workers. Migrants work substantially more than other types. Migrants are younger than individuals in rural and urban samples (average ages are 30.7, 46.7 and 42.5 respectively) and more often single. Yet the greater variance in marital and family status and age compared to 
the two other types conveys that the population of migrants is relatively mixed. Note that potential selection issues are discussed at the end of the paper. The rural sample contains mostly male household heads, while the proportion of females among migrant and urban individuals are very similar. Urban people are more educated than migrants, themselves more educated than rural workers. Urban's health scores are lower than for other groups, and higher for migrants, which may reflect differences in age between the groups. Urban people earn more than migrants, who, in turn, earn more than rural workers $(2,376,1,625$ and 1,369 Yuan/month respectively). Urban people acquire substantially more insurance compared to migrants and rural people.

Table B.1 also reports further characteristics concerning migrants. In particular, the presence of their family in urban areas, the proximity to other migrants and holding longterm or permanent contracts seem to be positively correlated with migrants' SWB. We also use a variable on "hypothetical rural income" corresponding to the question "if you were still in your home village, how much do you estimate you could earn every month? (Yuan/Month)". The average duration of stay (years since migration) is 8 years and the median is $6 .^{8}$

\subsection{Empirical Approach}

The methodology used in this paper is based on simple regressions of subjective well-being (SWB) on determinants including the income of a reference group aimed at testing relative concerns. The SWB or latent utility function of an individual is modeled as follows:

$$
S W B_{i}^{*}=\alpha \log \left(y_{i}\right)+\beta^{k} \log \left(\bar{y}_{i}^{k}\right)+Z_{i}^{\prime} \gamma+u_{i}
$$

In this equation, SWB is measured by the GHQ-12 index described previously and specified as a linear function of (log) absolute income, $y_{i}$, (log) income of a reference group $k, \bar{y}_{i}^{k}$, and a set of controls, $Z_{i}$. The latter are potential determinants of SWB as often used in the literature, including age, marital status, education, health status, number of children, work hours, salaried worker (versus self-employed) and access to social security. Given the ordered nature of the SWB score, the model is estimated as an ordered

\footnotetext{
${ }^{8}$ Other variables, not reported, are available and concern the material living conditions and social networks. We also find that average SWB is relatively stable over years since migration even though migrants' average income increases substantially (evidence available from the authors). This pattern is very similar to the Easterlin paradox (see Easterlin, 1995, 2010 for a recent overview): we may expect that immigrants who stay longer in host cities develop urban-specific human capital, improve their financial situation and hence their level of well-being; in fact, they also experience possible changes in relative concerns and income aspirations that attenuate the increased satisfaction derived from improvement in absolute material conditions. This is itself the subject of future research, but further motivates the following enquiry about migrants' relative concerns.
} 
probit (Ferrer-i-Carbonell and Frijters, 2004, show that OLS results when treating the aggregated GHQ answers as a continuous variable are very similar).

Results in the following section focus essentially on the estimates of coefficients $\alpha$ and $\beta^{k}$. The former coefficient is expected to be positive, so higher income should be associated with higher levels of well-being. However, our main interest is the sign of $\beta^{k}$, which is the impact of the relative income of relevant others $k$, and is a priori undetermined. As explained before, the definition of a reference group and the "typical income" inside this group, $\bar{y}_{i}^{k}$, are crucial aspects in the present exercise (see Senik, 2009, for a discussion). The main practice in the literature is to select the inhabitants of the geographical area where the respondent lives, then to refine by interacting geographical proximity with other dimensions (e.g., age, cohort, standard of living, and combinations of these in McBride, 2001; age, education and occupation groups in Clark and Oswald, 1996, and Ferrer-iCarbonell, 2005). ${ }^{9}$ We follow the bulk of the literature, and acknowledge the possibly ad hoc choices made to construct reference groups, but suggest a systematic exploration of alternative orbits of comparison for the three types (rural, urban and migrants) and alternative comparison groups for the migrant workers in particular. ${ }^{10}$ In addition, we test different "typical income" measures $\bar{y}_{i}^{k}$, either the mean, the median income or other points of the income distribution of the reference group $k$.

\footnotetext{
${ }^{9}$ The scope of the geographical reference varies, from being as large as East and West Germany (Ferrer-i-Carbonell, 2005) or American States (Blanchflower and Oswald, 2004), to smaller areas such as the primary census units of the American National Survey of Families and Households (Luttmer, 2005). When direct evidence is available, spheres of comparisons may be more specific, e.g., according to Knight et al. (2009), $68 \%$ of Chinese rural respondents report that their main comparison group consists of individuals in their own village.

${ }^{10}$ Reference labor income may be interpreted in a professional sense (see Senik, 2008). Yet, when focusing on migrants, some of the reference groups we define may include people with whom migrants have more personal links (community ties). Clark and Senik (2010) show that comparisons to family members and friends do not carry the same informational value as comparisons to potential competitors on the labor market. In the former case, positive relative income effects may reveal altruism. In the latter, envy may conflict with a possible information or signal effect when people compare to professional peers in order to acquire information about their professional future. We try to disentangle the two aspects in what follows.
} 


\section{Results}

\subsection{Determinants of Subjective Well-Being and Benchmark Re- sults}

Before turning specifically to the relative concerns of rural-to-urban migrants, we suggest in this sub-section a comprehensive analysis of SWB in the three populations of rural, migrant and urban workers. For this purpose, we estimate equation (1) for each type separately and use different reference groups as described below. Our aim is to check whether standard results regarding the determinants of SWB apply when using the novel dataset at hand. We also would like to check the sensitivity of our results to the choice of reference groups (and of relative income measures).

General SWB Determinants Results of benchmark estimations are presented in Table 2. The signs and significance of the parameters for usual socio-economic and demographic characteristics are in line with standard findings in the literature (e.g., Frey and Stutzer, 2002, and the review by Dolan et al., 2008). Health, education, income, housing and marriage are some of the most often considered factors found to have positive relationships with SWB (van Praag et al., 2003). We find a particularly strong impact of health variables, all dummies other than "very good health" (the omitted category) leading to a sharp drop in well-being. We find a positive and significant effect of education, yet the relationship is somewhat weak as previously reported (Fuentes and Rojas 2001; Helliwell, 2003). We also confirm a positive correlation between marriage and SWB (e.g., Argyle, 1999; Helliwell, 2003). Often in the literature the presence of children does not tend to increase SWB very significantly and sometimes exerts a negative effect (e.g., Glenn and Weaver, 1978). We find here a positive and significant effect for rural workers - who incidentally are those less constrained by the one-child policy - and insignificant effects otherwise. A U-shape relationship between age and happiness is usually observed (e.g., in Blanchflower and Oswald, 2004) and is confirmed here for rural workers. When controlling for all these characteristics, being female has no impact, except for migrants, for whom it is negative and significant (Clark and Oswald, 1994). Salary workers also report lower SWB compared to the self-employed among rural and migrant workers (Benz and Frey, 2008). Unemployment insurance is positively and significantly related to SWB for the urban people but does not seem to matter for rural and migrant people. This is reversed in the case of pension insurance (rural households seem to value access to pension systems). Injury insurance seems to positively affect the SWB of migrants, who are likely exposed to more difficult working conditions. Note that pseudo R-squared are small but 
that it is usual in the SWB literature (see Clark et al., 2008). In fact, the magnitude of the McFadden R-squared is known to be difficult to interpret (see Veall and Zimmermann, 1996), so we also report R-squared when treating the dependent variable as continuous.

Absolute and Relative Incomes As expected, richer individuals report higher SWB ceteris paribus, with positive and significant $\alpha$ coefficient in all cases. It is noticeably larger among urban workers, possibly denoting a more materialistic life in urban areas (see Knight and Gunatilaka, 2010a). In these benchmark estimations, the relative income is calculated as the mean income of all workers of the same type (rural, urban and migrant) in the same local district (which corresponds to a city, for urban and migrants). The effect is positive for the rural individuals (0.133) but not significant. ${ }^{11}$ The relative income effect is negative and highly significant for the migrants and urban workers (-0.352 and -0.384), which implies a strong status effect of migrants vis-à-vis other migrants and urban workers vis-à-vis other urban workers in the same city. The magnitude of the relative income effect is striking and suggests the important role of relative income as a determinant of SWB among migrant and urban workers. However, an alternative explanation is possible: relative labor income may in fact capture differences in local costs of living, to the extent that wages are correlated with prices. This may seem less of a concern when migrants compare themselves with other migrants, but this is certainly an issue in the urban case. For that reason, we control for spatial variation in prices using the data constructed by Brandt and Holz (2006). We use specific urban indices (for urban and migrant workers) and rural indices. Results show that price levels have the expected depressing effect on well-being in the case of rural workers only. ${ }^{12}$ Most importantly, we find that relative income effects remain strongly significant for urban and migrant workers, and the order of magnitude is very similar, whether we control for price variation or not (alternative estimations available from the authors). ${ }^{13}$ It is more difficult to comment on the magnitude of relative income effects, but larger coefficients compared to absolute income effects are not unusual (e.g., in Knight et al., 2009; Senik, 2008).

\footnotetext{
${ }^{11}$ Insignificant effects could be related to the very low absolute income level. Indeed, the relative concerns may not kick in until the income level of the society goes beyond the subsistence level (Clark et al., 2008).

${ }^{12}$ For urban and migrant workers, the effect is positive but very small. This is certainly due to the fact that labor income and prices are highly correlated at the province level - and by construction at the district level, as we observe only a few districts per province - for migrants (correlation of .62) and urban (.81), less so for rural workers (.36).

${ }^{13}$ Results are also very similar when the price index is introduced in log terms. The interpretation in that case is that well-being depends on log real income. See Luttmer (2005) for an extended discussion.
} 
Table 2: Determinants of Subjective Well-being: Benchmark Results

\begin{tabular}{|c|c|c|c|c|c|c|c|}
\hline & Rural workers & Migrants & Urban workers & & Rural workers & Migrants & Urban workers \\
\hline Log absolute income & $\begin{array}{l}0.116 \text { *** } \\
(0.029)\end{array}$ & $\begin{array}{l}0.095 \text { *** } \\
(0.034)\end{array}$ & $\begin{array}{l}0.165 \text { *** } \\
(0.051)\end{array}$ & Health: poor & $\begin{array}{l}-1.142 \text { *** } \\
(0.162)\end{array}$ & $\begin{array}{l}-1.172 * * * \\
(0.138)\end{array}$ & $\begin{array}{l}-1.428 \text { *** } \\
(0.180)\end{array}$ \\
\hline Log relative income@ & $\begin{array}{r}0.133 \\
(0.092)\end{array}$ & $\begin{array}{l}-0.352 * * * \\
(0.117)\end{array}$ & $\begin{array}{l}-0.384 \text { ** } \\
(0.181)\end{array}$ & Health: very poor & $\begin{array}{l}-1.992 * * * \\
(0.525)\end{array}$ & $\begin{array}{l}-1.457 \text { *** } \\
(0.437)\end{array}$ & $\begin{array}{l}-1.629 \text { *** } \\
(0.182)\end{array}$ \\
\hline Spatial price index $/ 100$ & $\begin{array}{l}-0.057 \text { *** } \\
(0.018)\end{array}$ & $\begin{array}{c}0.008 * \\
(0.005)\end{array}$ & $\begin{array}{r}0.003 \\
(0.011)\end{array}$ & 0 child & $\begin{array}{r}0.077 \\
(0.158)\end{array}$ & $\begin{array}{l}-0.105 \\
(0.118)\end{array}$ & $\begin{array}{r}0.284 \\
(0.275)\end{array}$ \\
\hline Salary worker (vs. self-emp.) & $\begin{array}{l}-0.123 \text { ** } \\
(0.052)\end{array}$ & $\begin{array}{l}-0.105 \text { ** } \\
(0.045)\end{array}$ & $\begin{array}{l}-0.005 \\
(0.089)\end{array}$ & 1 child & $\begin{array}{r}0.107 \\
(0.077)\end{array}$ & $\begin{array}{l}-0.117 \\
(0.095)\end{array}$ & $\begin{array}{r}0.200 \\
(0.254)\end{array}$ \\
\hline Hours of work & $\begin{array}{l}-0.107^{* *} \\
(0.044)\end{array}$ & $\begin{array}{l}-0.337 \text { *** } \\
(0.077)\end{array}$ & $\begin{array}{l}-0.090 \\
(0.070)\end{array}$ & 2 children & $\begin{array}{l}0.140 \text { ** } \\
(0.070)\end{array}$ & $\begin{array}{l}-0.085 \\
(0.094)\end{array}$ & $\begin{array}{r}0.373 \\
(0.262)\end{array}$ \\
\hline Age & $\begin{array}{l}-0.054^{* *} \\
(0.026)\end{array}$ & $\begin{array}{l}-0.012 \\
(0.012)\end{array}$ & $\begin{array}{r}0.003 \\
(0.028)\end{array}$ & Weight & $\begin{array}{r}0.004 \\
(0.003)\end{array}$ & $\begin{array}{r}0.002 \\
(0.002)\end{array}$ & $\begin{array}{l}-0.002 \\
(0.003)\end{array}$ \\
\hline Age squared & $\begin{array}{c}0.063 \text { ** } \\
(0.027)\end{array}$ & $\begin{array}{r}0.016 \\
(0.015)\end{array}$ & $\begin{array}{l}-0.001 \\
(0.032)\end{array}$ & Height & $\begin{array}{r}0.008 \\
(0.005)\end{array}$ & $\begin{array}{l}-0.004 \\
(0.003)\end{array}$ & $\begin{array}{r}0.000 \\
(0.006)\end{array}$ \\
\hline Female & $\begin{array}{l}-0.157 \\
(0.162)\end{array}$ & $\begin{array}{l}-0.175 \text { *** } \\
(0.046)\end{array}$ & $\begin{array}{r}0.035 \\
(0.080)\end{array}$ & Education (years) & $\begin{array}{l}0.028^{* * *} \\
(0.010)\end{array}$ & $\begin{array}{l}0.033^{* * *} \\
(0.007)\end{array}$ & $\begin{array}{c}0.021 \text { ** } \\
(0.011)\end{array}$ \\
\hline Married & $\begin{array}{c}0.401 \text { ** } \\
(0.172)\end{array}$ & $\begin{array}{l}0.217 \text { *** } \\
(0.067)\end{array}$ & $\begin{array}{l}0.374 \text { *** } \\
(0.106)\end{array}$ & Unempl. insurance & $\begin{array}{r}0.036 \\
(0.099)\end{array}$ & $\begin{array}{r}0.087 \\
(0.066)\end{array}$ & $\begin{array}{c}0.133 * \\
(0.069)\end{array}$ \\
\hline Health: good & $\begin{array}{l}-0.492 \text { *** } \\
(0.055)\end{array}$ & $\begin{array}{l}-0.469 \text { *** } \\
(0.033)\end{array}$ & $\begin{array}{l}-0.568 \text { *** } \\
(0.072)\end{array}$ & Pension insurance & $\begin{array}{l}0.169 \text { *** } \\
(0.060)\end{array}$ & $\begin{array}{l}-0.176 \text { *** } \\
(0.056)\end{array}$ & $\begin{array}{r}0.007 \\
(0.077)\end{array}$ \\
\hline Health: average & $\begin{array}{l}-0.863 \text { *** } \\
(0.073)\end{array}$ & $\begin{array}{l}-0.777 \text { *** } \\
(0.049)\end{array}$ & $\begin{array}{l}-0.959 \text { *** } \\
(0.084)\end{array}$ & Injury insurance & $\begin{array}{r}0.046 \\
(0.069)\end{array}$ & $\begin{array}{l}0.211 \text { *** } \\
(0.057)\end{array}$ & $\begin{array}{l}-0.045 \\
(0.064)\end{array}$ \\
\hline $\begin{array}{l}\text { Pseudo R2 (oprobit) } \\
\text { R2 (OLS) } \\
\text { \# observations }\end{array}$ & $\begin{array}{r}0.043 \\
0.135 \\
2177\end{array}$ & $\begin{array}{r}0.035 \\
0.115 \\
4878\end{array}$ & $\begin{array}{r}0.040 \\
0.130 \\
1860\end{array}$ & \multicolumn{4}{|c|}{$\begin{array}{l}\text { Note: } *, * *, * * * \text { indicate significance levels at } 1 \%, 5 \% \text { and } 10 \% \\
\text { respectively. @: Reference groups for "relative income": same type } \\
\text { (rural, urban, migrant), living in same district/city. }\end{array}$} \\
\hline
\end{tabular}


Reference Group Definition In Table 3 we employ a sensitivity analysis of the reference group definition. Due to lack of space, we only report the coefficients $\alpha$ and $\beta^{k}$ (indicated as AI and RI for absolute income and relative income effects) in the three separate regressions, standard errors and pseudo R-squared. For each type the reference group is based on the same type (for example rural compared themselves to rural) and various orbits of comparison. The first set of coefficients where reference groups are of the same district correspond to the benchmark estimations in Table 2.

The next set refines the reference group by considering all same-type workers of the same district and age group. There is naturally a trade-off between cell size and how precise the reference group can be, and this problem is particularly acute with age proximity. We suggest two different ways of calculating age groups: one using a window of \pm 5 years around a worker's own age, another with three broad age groups and hence large cell sizes (under 30, 30-45, 45+). ${ }^{14}$ The relative income effect becomes weaker with the former strategy - only the status effects among migrants remains significant - reflecting the fact that narrowly defined age groups reduce the size of reference groups too much to remain meaningful. Results are somewhat intermediary when using three broader age groups, which we adopt in the remaining of the paper, yet the status effect for urban workers is no longer significant.

Next, we calculate reference groups at the province level rather than district. This does not make much difference for urban and migrant workers because these are sampled in 15 cities allocated over 10 main emigration and immigration provinces (hence the variation that generates the results across cities or districts is not much larger than that across provinces). ${ }^{15}$ For rural workers, however, we notice that the relative income effect becomes partially significant and positive. Previous results at the district level were in fact not very informative for rural workers because of the very small sample size of reference groups in that case (the average number of rural observations per district is 28 , compared to 325 for migrants). Arguably, the province level (or even the district level) mayb be too broad to capture precise comparison groups. Nonetheless, our results tend to corroborate the positive effects found in Bookwalter and Dalenberg (2010) and Kingdon and Knight (2007) for South Africa - interpreted in terms of altruism and a sense of community. Minor evidence of such positive relative income effect is also found for broad rural groups in China in the study of Knight et al. (2009).

\footnotetext{
${ }^{14}$ Sensitivity analysis on cell sizes and definition of reference groups can be found in McBride (2001) and Ferrer-i-Carbonell (2005).

${ }^{15}$ Without more district variations, there is unfortunately no way we can prove that province is not a relevant level when constructing reference groups for these types.
} 
Mean or Distribution Points In the lower panel of Table 3, we depart from the "typical income" measured as the mean income of the reference group. For migrants we see that results are qualitatively the same when the median income is used instead, showing that results are not driven by outliers that would push mean income levels up. The relative income effect for rural and urban workers become significant when using the median, whether or not the age criterion is applied. For rural workers, the median may help to escape from the outlier problem and to capture better the local reference income these workers may have in mind. The same issue may actually be solved here for urban workers, for whom the average number of observations per district (city) is not very large either $(115){ }^{16}$

Other points in the distribution, such as the 25 th and 75 th percentiles, may also be used, but meaningful interpretations in that case require that reference groups are not too small, for instance, the age criterion would have to be ignored. For both migrants and urban workers in this case, the 25th and 75th percentiles lead to significant and negative relative income effects (not reported); for rural workers only the 25 th percentile gives a positive and significant effect.

A last check is whether we should be concerned about asymmetries that may exist in the way relative income affects well-being. Hence, for the last results of Table 3 we use type and district (for migrant and urban workers) or province (for rural workers) as the criteria defining reference groups but allow for different effects whether workers are below or above the median income. For all types we essentially find that relative income matters on both sides of the median and that the effects are very similar. Results are fairly stable for migrants once age is added to the composition of reference group or once the mean rather than the median is used. This lends some confidence about the robustness of results concerning relative concerns of migrants, and the core of our analysis as presented in the next sub-section.

Additional Checks on Urban and Rural Workers Before turning to migrants, we provide a last series of checks based on urban and rural workers. With the aim of validating the empirical approach used, our purpose is to check whether the relative income effects obtained above are meaningful or due to possible spurious correlation. To do so, we test whether implausible (or irrelevant) reference groups could also appear significant in our regressions. Based on the conclusions above, and to reduce problems of cell size, we make use of median incomes and use province level variation for rural

\footnotetext{
${ }^{16}$ When group size becomes even smaller, for instance, when age is used, this is certainly an issue. This would explain why, in previous results, we found significant relative concerns among urban workers only when broad reference groups where used (but not when refining using age).
} 
Table 3: Absolute and Relative Income Effects: Sensitivity to Reference Group Definition

\begin{tabular}{|c|c|c|c|c|c|}
\hline \multirow{2}{*}{$\begin{array}{l}\text { Reference groups: workers of } \\
\text { same type (rural/migrant/urban), }\end{array}$} & \multirow{2}{*}{ Measure: } & & \multicolumn{3}{|c|}{ Selected samples: } \\
\hline & & & Rural workers & Migrants & Urban workers \\
\hline \multirow{4}{*}{ And same district } & \multirow{4}{*}{ mean income } & $A I$ & 0.116 *** & $0.095 * * *$ & 0.165 *** \\
\hline & & & 0133 & $-0.352 * * *$ & $-0.384 * *$ \\
\hline & & $R I$ & $(0.092)$ & $(0.117)$ & $(0.181)$ \\
\hline & & pseudo R2 & 0.043 & 0.035 & 0.040 \\
\hline \multirow{4}{*}{ And same district \& age $( \pm 5$ years $)$} & \multirow{4}{*}{ mean income } & $A I$ & $\begin{array}{l}0.100 \text { *** } \\
(0.032)\end{array}$ & $\begin{array}{c}0.085 \text { ** } \\
(0.036)\end{array}$ & $\begin{array}{l}0.149 \text { *** } \\
(0.052)\end{array}$ \\
\hline & & $R I$ & 0.098 & $-0.245 * *$ & -0.108 \\
\hline & & $\mathrm{K} I$ & $(0.084)$ & $(0.108)$ & $(0.159)$ \\
\hline & & pseudo R2 & 0.042 & 0.035 & 0.042 \\
\hline \multirow{4}{*}{ And same district $\&$ age ( 3 groups) } & \multirow[t]{4}{*}{ mean income } & & $\begin{array}{l}0.119 \text { *** } \\
(0.030)\end{array}$ & $\begin{array}{l}0.101 \text { *** } \\
(0.034)\end{array}$ & $\begin{array}{l}0.160 \text { *** } \\
(0.050)\end{array}$ \\
\hline & & $R I$ & 0.085 & $-0.398 * * *$ & -0.194 \\
\hline & & & $(0.080)$ & $(0.098)$ & $(0.150)$ \\
\hline & & pseudo R2 & 0.043 & 0.036 & 0.040 \\
\hline \multirow{4}{*}{ And same province $\&$ age ( 3 groups) } & \multirow{4}{*}{ mean income } & $A I$ & $\begin{array}{l}0.120 \text { *** } \\
(0.029)\end{array}$ & $\begin{array}{l}0.091 \text { *** } \\
(0.034)\end{array}$ & $\begin{array}{l}0.158 \text { *** } \\
(0.050)\end{array}$ \\
\hline & & $R I$ & $0.223 *$ & $-0.311 * * *$ & -0.273 \\
\hline & & & $(0.127)$ & $(0.100)$ & $(0.201)$ \\
\hline & & pseudo R2 & 0.043 & 0.035 & 0.040 \\
\hline \multirow{4}{*}{ And same district } & \multirow{4}{*}{ median income } & $A I$ & $\begin{array}{c}0.107^{* * *} \\
(0.030)\end{array}$ & $\begin{array}{c}0.120 * * * \\
(0.035)\end{array}$ & $\begin{array}{c}0.170 \text { *** } \\
(0.051)\end{array}$ \\
\hline & & & $0.211 * *$ & $-0.741 * * *$ & $-0.387 * * *$ \\
\hline & & $\mathrm{K} I$ & $(0.082)$ & $(0.112)$ & $(0.139)$ \\
\hline & & pseudo R2 & 0.044 & 0.037 & 0.041 \\
\hline \multirow{4}{*}{ And same district $\&$ age ( 3 groups) } & \multirow{3}{*}{ median income } & $A I$ & $\begin{array}{l}0.112 \text { *** } \\
(0.030)\end{array}$ & $\begin{array}{l}0.112 \text { *** } \\
(0.035)\end{array}$ & $\begin{array}{l}0.164 \text { *** } \\
(0.050)\end{array}$ \\
\hline & & $R I$ & $0.130 *$ & $-0.532 * * *$ & $-0.212 *$ \\
\hline & & treuda R2 & $\begin{array}{r}(0.074) \\
0.043\end{array}$ & $\begin{array}{r}(0.096) \\
0.036\end{array}$ & $\begin{array}{r}(0.111) \\
0.040\end{array}$ \\
\hline & & & & & \\
\hline \multirow[t]{6}{*}{ And same district } & \multirow[t]{6}{*}{ median income } & $A I$ & $0.103 * * *$ & $0.124 * * *$ & 0.083 *** \\
\hline & & & $(0.034)$ & $(0.049)$ & $(0.065)$ \\
\hline & & RI (below median) & $\begin{array}{l}0.138 \text { *** } \\
(0.076)\end{array}$ & $\begin{array}{l}-0.543 \text { *** } \\
(0.100)\end{array}$ & $\begin{array}{l}-0.159 \text { *** } \\
(0.114)\end{array}$ \\
\hline & & RI (ahove median) & $0.142 *$ & $-0.545 *$ & $-0.137 *$ \\
\hline & & NI (above mearan) & $(0.078)$ & $(0.101)$ & $(0.116)$ \\
\hline & & pseudo R2 & 0.043 & 0.036 & 0.041 \\
\hline \#Observations & & & 2,180 & 4,878 & 1,863 \\
\hline
\end{tabular}

Note: $* * *, * * *$ indicate significance levels at $1 \%, 5 \%$ and $10 \%$ respectively. AI and RI denote the coefficients on absolute income and relative income respectively. Two age group definitions are used: \pm 5 years around the worker's age or 3 groups (under 30, 30-45, 45+). Same type means that the reference group for rural workers is the mean income of other rural workers only (possibly in the same age group). Robust standard errors are reported in brackets. 
workers. We suggest three specifications. In the first, I, workers compare themselves to people of the same type (urban to urban, rural to rural). In the second, II, they are compared to a group which is a priori irrelevant (for urban workers: the income of migrants living in the same city; for rural workers: the income of urban people living in the same province). Specification III incorporate the two groups at the same time. In Appendix Table B.2 (left panel), we report the results for urban workers. Specification I gives the same results as in Table 3 (urban workers compare themselves to other urban people of the same city, and possibly same age group). Specification II shows that the median income of migrants has no effect on urban workers' well-being. Specification III confirms these results when the two reference groups are used simultaneously. Results are robust to the introduction of age in the reference group definition. The right panel examines rural workers. Specification I gives the same result as when using province-based reference groups in Table 3: a significantly positive relative concern among rural workers. Specification II shows that rural workers have no sentiments for the labor income levels of urban workers in the same province, and specification III confirms these results when using both groups simultaneously.

\subsection{Relative Concerns of Migrants}

We now provide an extensive analysis of the relative concerns of migrant workers. The main set of results is presented in Table 4. Due to a lack of space, we report only the relative income effect for alternative reference groups (described hereafter). The first column shows the main estimation results, as above, while the following columns show effects for different durations of stay ("years since migration"). ${ }^{17}$ Among non-reported estimates, note that absolute income effects are always positive, usually significant and with a fairly stable size (available upon request). Other variables $Z_{i}$ are the same as before, except with the inclusion of "years since migration" and the square of it as additional controls. These variables are significant and show that SWB decreases then increases with the duration of stay, reflecting possible assimilation periods.

Rural Workers as a Reference Group Migrants are from rural areas, and so it is natural to assume that they may compare themselves with rural workers of source regions. The data allows us to link migrants to their home province, and hence, we use the rural sample to obtain a measure of rural median income per province. ${ }^{18}$ As seen in Table 1,

\footnotetext{
${ }^{17}$ These effects for particular groups are obtained in a single regression where $\bar{y}_{i}^{k}$ is replaced by its interaction with dummy variables for years-since-migration equal to 1-3, 4-6, 7-10 and 11+.

${ }^{18}$ It would be interesting to use districts of origin rather than province of origin. However, the rural data is a random sample that is not exclusively matched with migrants, hence only a few rural observations
} 
we identify a total of 4,536 household heads that migrated from one of the nine provinces where rural observations are available (another 732 migrants come from other provinces of which we have no information). There are very few rural workers in provinces $6,9,10$ and when these provinces are dropped, we obtain a final selection of 3,752 migrants (and very similar results when all provinces are included). As explained before, several forces may be at play: a status effect may well exist for migrants who expect to improve their financial conditions in urban areas compared to home provinces. Simultaneously, altruistic feelings toward home regions may exist (remember that the relative concern of rural workers when compared with themselves is actually positive). The results reported in the top panel of Table 4 show that the status effect clearly dominates, with a significant and negative relative income effect overall. Perhaps more surprising is that this effect is of constant magnitude whatever the duration of stay. It could be expected that after some years since migration, relative concerns for home regions would fade away. However, we should not forget that the sample is composed of different types of migrants. The intuition above may well apply to those who wish to stay in cities forever ( $57 \%$ of the migrant sample) and for them the status effect may indeed decline over time. However, it is not clear that the $43 \%$ who plan to return to home regions one day have strong competitive feelings toward home regions. We investigate this point further below.

Given the ad hoc definition of reference groups and, in the case of rural comparison points, the very small regional variation (six provinces), results above could simply be due to spurious correlation. In the following rows of Table 4, we suggest a simple way of testing this. Instead of allocating migrants to their own province of origin, we assign each of them to randomly selected provinces. With these implausible and irrelevant reference groups, the relative income effect becomes insignificant. This gives confidence in the results above despite the small number of provinces used in the regressions.

Finally, migrants are in general younger than the rural people left behind. Thus, the rural reference group compares young migrants with older rural people in the source regions (potentially parents, older relatives etc.). One may suggest comparing migrants with workers of the same cohort. Two obvious issues arise. Firstly, given the magnitude of the migration phenomenon in China, it is possible that those "left behind" are too few or too weekly representative of what an alternative life could be for the migrants. Secondly, the age criterion may lead to the aforementioned problem of comparison cells being too small. For these reasons we suggest an original comparison based, for each migrant, on the reported hypothetical rural income of all other migrants of the same origin and age group, wherever their location in China. This is an interesting comparison measure, which can could be found for the exact source district of each migrant. 
be used to construct proxies of (virtual) rural-based reference income of same-generation workers. It transpires that this reference income leads to very strong status effect. We cannot preclude, however, that this result reflects rivalries among migrants of the same origin and same cohort. ${ }^{19}$ We then turn to a set of estimations specifically examining other migrants as a potential reference group.

Other Migrants as a Reference Group We construct several reference groups based on "relevant other migrants", starting with migrants living in the same city. With the large migrant sample, we can refine the reference group by adding the age criterion or, alternatively, duration of stay (i.e., we construct reference groups composed of migrants living in the same city and whose duration of stay is in a window of three years around a worker's own years-since-migration). These three sets of results are reported in the intermediary part of Table 4 . We observe a strong status effect: migrants compete with migrants. The effect is larger when narrowing down the reference group to the same age group and stronger still when considering migrants with the same migration history. In the last row of the middle panel, we add same-origin as a last criterion. In this case, status effect toward migrants of same origin, with the same migration history and present in the same city exists, but it is much smaller than previously found. These particular migrants are potentially those who interact on a daily basis and form a community within which altruism and reciprocal interests cannot be excluded.

Urban Workers as a Reference Group The third obvious comparison group is made of all urban workers living in the city where migrants have settled. Since the migrant sample is essentially collected in the same cities as the urban sample, direct comparisons can be established. To proxy the relative concerns of migrants toward urban people, we use the median income of all urban workers in the same city where the migrant lives. It may well be the case that migrants compare themselves to the whole urban population if their intention is to stay and prosper in the city. However, contrary to comparisons with other migrants, the urban people may be slightly less comparable in terms of observed attributes such as age. Therefore, we also narrow down this reference group to urban workers in the same city and same age group.

The last panel of Table 4 points to a positive relative concern - this result, one of the most prominent findings in this paper, deserves particular attention. First of all, we observe that it is significant only when age groups are used, which could indicate

\footnotetext{
${ }^{19} \mathrm{In}$ fact, the correlation between actual labor income and hypothetical rural income across all those migrants is not as high as expected (only .25). When labor income is used in place of hypothetical rural income, however, a significant status effect is also found, but with a slightly lower magnitude.
} 
that migrants indeed build aspiration based on people of similar age. Then we suggest several explanations for this positive positional concern. A first obvious argument could be related to pure economic externalities. Thus, relative income acts as a proxy for the benefits of living with rich(er) people and in particular the presence of higher levels of public goods and services in wealthy neighborhoods. If this was the case, however, the relative income of the whole urban group (and not only people of the same age) should appear significantly as a public good indicator. Moreover, we check this point further by explicitly including a measure of the quality of public services at the city level in the regression. We make use of the 2009 survey released by the Shanghai Jiao Tong University (RCEMS, 2009). ${ }^{20}$ We find that the public service score variable has a positive and highly significant effect on migrant well-being. Most importantly, the effect of relative income is hardly affected by the introduction of this variable, as can be seen in the last rows of Table 4. It still has a significantly positive effect of its own. A second interpretation is altruism. However, and contrary to the positive concern found among rural workers, it is unlikely that migrants develop deep altruistic feelings toward urban residents. The third, and most likely, interpretation of the positive effect of urban income is the signal effect: urban residents' higher incomes may be informative about migrants' own future income. Evidence can be found in low-income countries (and in particular South Africa), as already mentioned, but also for Russia (Senik, 2004), Eastern European countries and the US (Senik, 2008). ${ }^{21}$ Countries where the degree of perceived income mobility is high also tend to generate positive concerns related to this signal or tunnel effect. In particular, Senik (2008) finds that higher reference group income raises well-being in the United States and in the post-transition countries of Eastern Europe. Senik also finds that relative income is more strongly positively correlated with life satisfaction for those in more uncertain situations (as measured by the volatility of their income and the probability of losing their job). This line of argument seems to apply particularly well to migrants in China, whose job situation is on average more insecure than that of urban residents (on this point, see Meng and Zhang, 2010, and Qu and Zhao, 2011).

We may expect a decline of this signal effect over years since migration. For one thing, aspirations based on urban standards of living may diminish after several years in the city. A possible composition effect may also enter into the picture: for instance, status

\footnotetext{
${ }^{20}$ This survey, covering 35 major cities in China, was designed to measure residents and private businesses' perception and attitudes toward the quality of public service delivery in respective cities, covering areas such as education, public safety, public health, infrastructure, transport, public policy-making and enforcement.

${ }^{21}$ In unstable economies like Russia's, individuals would take the reference income not as a comparison but as an information measure to create future expectations. See also Ravallion and Lokshin (2000).
} 
effect may play a bigger role for older migrants and counteract signal effects. Indeed, older migrants have had time to develop urban-specific human capital and find themselves more in competition with urban workers. We indeed observe a slightly decreasing trend in our result but it is not significant. As argued above for rural reference groups, the composition of the sample - and the large share of temporary migrants whose SWB is likely less affected by urban comparison points - may make that this trend is less pronounced than expected.

Table 4: Relative Income Effects of Migrants

\begin{tabular}{|c|c|c|c|c|c|c|}
\hline \multirow{2}{*}{ Ref. group } & \multirow{2}{*}{ All } & \multicolumn{4}{|c|}{ "Year since migration : } & \multirow{2}{*}{ \# obs. @ } \\
\hline & & $1-3$ & $4-6$ & $7-10$ & $11+$ & \\
\hline Rural, same home province & $\begin{array}{l}-0.291 * * * \\
(0.111)\end{array}$ & $\begin{array}{l}-0.282 \text { ** } \\
(0.112)\end{array}$ & $\begin{array}{l}-0.288 \text { *** } \\
(0.111)\end{array}$ & $\begin{array}{l}-0.299 \text { *** } \\
(0.111)\end{array}$ & $\begin{array}{l}-0.294 \text { *** } \\
(0.112)\end{array}$ & 3752 \\
\hline Rural, random province & $\begin{array}{l}-0.055 \\
(0.111)\end{array}$ & $\begin{array}{l}-0.050 \\
(0.112)\end{array}$ & $\begin{array}{l}-0.054 \\
(0.111)\end{array}$ & $\begin{array}{l}-0.057 \\
(0.111)\end{array}$ & $\begin{array}{l}-0.056 \\
(0.112)\end{array}$ & 3752 \\
\hline Migrants, same province $\&$ age $£$ & $\begin{array}{l}-0.564 * * * \\
(0.087)\end{array}$ & $\begin{array}{l}-0.554 \text { *** } \\
(0.089)\end{array}$ & $\begin{array}{l}-0.559 * * * \\
(0.088)\end{array}$ & $\begin{array}{l}-0.568 \text { *** } \\
(0.087)\end{array}$ & $\begin{array}{l}-0.574 * * * \\
(0.088)\end{array}$ & 4878 \\
\hline Migrants, same city & $\begin{array}{l}-0.349 \text { *** } \\
(0.118)\end{array}$ & $\begin{array}{l}-0.341 \text { *** } \\
(0.119)\end{array}$ & $\begin{array}{l}-0.343 \text { *** } \\
(0.119)\end{array}$ & $\begin{array}{l}-0.348^{* * *} \\
(0.118)\end{array}$ & $\begin{array}{l}-0.351 \text { *** } \\
(0.118)\end{array}$ & 4878 \\
\hline Migrants, same city \& age group & $\begin{array}{l}-0.394 * * * \\
(0.099)\end{array}$ & $\begin{array}{l}-0.391 \text { *** } \\
(0.100)\end{array}$ & $\begin{array}{l}-0.394 * * * \\
(0.100)\end{array}$ & $\begin{array}{l}-0.399 \text { *** } \\
(0.100)\end{array}$ & $\begin{array}{l}-0.400 * * * \\
(0.099)\end{array}$ & 4878 \\
\hline Migrants, same city \& YSM & $\begin{array}{l}-0.430 * * * \\
(0.118)\end{array}$ & $\begin{array}{l}-0.440 * * * \\
(0.119)\end{array}$ & $\begin{array}{l}-0.431 \text { *** } \\
(0.119)\end{array}$ & $\begin{array}{l}-0.425 * * * \\
(0.118)\end{array}$ & $\begin{array}{l}-0.427 \text { *** } \\
(0.118)\end{array}$ & 4878 \\
\hline Migrants, same city, YSM \& origin & $\begin{array}{l}-0.135 * \\
(0.073) \\
\end{array}$ & $\begin{array}{l}-0.129 * \\
(0.075) \\
\end{array}$ & $\begin{array}{c}-0.130 * \\
(0.075) \\
\end{array}$ & $\begin{array}{l}-0.134 * \\
(0.074) \\
\end{array}$ & $\begin{array}{c}-0.136 * \\
(0.074) \\
\end{array}$ & 4878 \\
\hline Urbans of same city & $\begin{array}{r}0.096 \\
(0.096)\end{array}$ & $\begin{array}{r}0.100 \\
(0.096)\end{array}$ & $\begin{array}{r}0.099 \\
(0.096)\end{array}$ & $\begin{array}{r}0.094 \\
(0.096)\end{array}$ & $\begin{array}{r}0.090 \\
(0.097)\end{array}$ & 4878 \\
\hline Urbans of same city \& age group & $\begin{array}{l}0.206 * * * \\
(0.045)\end{array}$ & $\begin{array}{l}0.212 \text { *** } \\
(0.046)\end{array}$ & $\begin{array}{l}0.208^{* * *} \\
(0.046)\end{array}$ & $\begin{array}{l}0.202 \text { *** } \\
(0.046)\end{array}$ & $\begin{array}{l}0.197 \text { *** } \\
(0.047)\end{array}$ & 4878 \\
\hline Urbans of same city \& age group \# & $\begin{array}{l}0.192 \text { *** } \\
(0.050)\end{array}$ & $\begin{array}{l}0.204 \text { *** } \\
(0.051)\end{array}$ & $\begin{array}{l}0.196 \text { *** } \\
(0.051)\end{array}$ & $\begin{array}{l}0.184 \text { *** } \\
(0.051)\end{array}$ & $\begin{array}{l}0.179 \text { *** } \\
(0.052)\end{array}$ & 4878 \\
\hline \multicolumn{7}{|c|}{$\begin{array}{l}\text { Note: Reference income is calculated as the median income of reference groups. We report only the relative income effects (RI) and their } \\
\text { standard errors in brackets. Absolute income effects are always positive, significant and fairly stable in magnitude, so we omit them to save on } \\
\text { space. Pseudo R2 are in range between } .034 \text { and } .038 \text {. YSM stands for years-since-migration (we use a } \pm 3 \text { year interval). }\end{array}$} \\
\hline \multicolumn{7}{|c|}{$\begin{array}{l}\text { @ When rural reference group is used: rural people are observed only in provinces } 1-10 \text {; hence, we must select only migrants from these province } \\
\text { and the sample becomes smaller than in the initial selection. }\end{array}$} \\
\hline \multicolumn{7}{|l|}{ f. Using hypothetical rural income } \\
\hline & & & & & & \\
\hline
\end{tabular}

Addressing Migrants' Heterogeneity Estimations discussed above were based on the full selection of migrants. However, migrants form a very complex group with different migration histories, different aspirations regarding urban life and different outcomes. As a first attempt to address heterogeneity among migrants, we use the question "if policy allowed, how long would you like to stay in the city?" in combination with migration history. A majority (54\%) of those who answer "forever" stayed more than six years in 
the city - the median duration time of the whole sample of migrants - while most of those who answer "less than 3 years" stayed a short time (63\% stayed less than six years).

Based on this information, we repeat the previous estimations separately on several groups, distinguishing between recent and old migration (less or more than six years) and between those who wish to stay permanently and those who prefer to eventually return. Results are presented in Table 5: compared to previous results, more pronounced patterns now emerge. First of all, only those who plan to stay, whether or not they arrived recently, seem to be competing with their home regions. The status effect is declining with time since migration, as we initially expected. In contrast, for those who plan to return to their rural regions and have been migrated for less than 6 years, the effect is basically zero. These people are similar to rural workers who have no (or positive) relative concerns vis-à-vis the rural reference group. Those who plan to return some day, but have been migrants for a longer time, show a status effect but it is insignificant.

For permanent stayers, the status effect vis-à-vis other migrants and the signal effect obtained with the urban reference group are also confirmed. Yet they are insignificant for those who may eventually return to rural regions. The latter may stay too short a while in urban areas to switch their reference group and adopt urban comparison points. For those who plan to stay, the status effect toward other migrants is especially strong when they arrived recently in the host region. Later on, the reference group may move toward a combination of migrants and other urban workers. This can explain why the status effect toward migrants decreases after some years since migration. It may also be due to conflicting feelings, as long-term migrants are part of a community possibly sharing altruistic feelings and reciprocal interests. In fact, when the reference group is local migrants of same origin, the effect becomes insignificant for those who want to stay forever. At the same time, relative concerns toward urban residents change, and the signal effect tends to fade away. For one thing, migrant aspiration has been confronted with the reality of urban life and the signal may lose its intensity. Also, as migrants assimilate and financial comfort increases, the signal effect conflicts more and more with growing status concerns toward urban counterparts. ${ }^{22}$ In any case, it is interesting to see that after some years in the cities, the reference groups do not necessarily change but their relative importance, and the feelings toward each of them, do evolve. ${ }^{23}$

\footnotetext{
${ }^{22}$ Interestingly, Knight and Gunatilaka (2010a) find a negative effect of urban incomes on migrants' SWB. A very likely reason for the difference with our results is that the migrant section in the CHIP2002, as used by these author, contained only settled, more permanent migrants, as explained in the data section above. Hence, they correspond more likely to our "permanent" migrants for whom status effects may eventually dominate any signal effect. Interestingly, the time trend is similar in both studies (the status effect gains ground with the length of stay).

${ }^{23}$ Of course, we cannot exclude that these results also reflect some selection among migrants. For
} 
Additional results are presented in Appendix Table B.3 using information on family background, job conditions, age and proximity to other migrants. For the latter, we use some information about whether migrants live close to other people of same origin in the city environment. Generally, those who do not live close to this community experience a strong status effect vis-à-vis rural income and vis-à-vis other migrants in the city. Let us characterize the four sub-groups represented in Table B.3. Among "recent" migrants who plan to eventually return to the home region (top left panel), we find very little signs of relative concern, except for workers who hold a permanent or long-term contract. For these, who represent half of this group, the status effects toward rural workers and other migrants is very strong, and so is the signal effect toward urban workers. For the others in this group, only some status concern toward other migrants can be observed in cases when these workers are weakly integrated in migrant communities. Interestingly, those with temporary contracts - possibly temporal migrant workers who want to return back to their hometown in the short-term - show a positive relative concern toward rural areas. This suggests that these workers may be very similar to rural workers and form their main reference group among rural workers of home regions. Those who do not wish to settle but have been in urban regions for a long time (top right panel) do not seem to have a urban reference group either - but show strong status effects toward rural workers and other migrants when not integrated in migrant communities in urban areas. Among those who have been migrants for less than 6 years but who wish to settle in cities (bottom left panel), the most interesting characteristic is precisely the strong relative concern toward urban workers: the sub-group of young workers whose aspirations are linked to careers in urban regions are those primarily experiencing a signal effect. Finally, "older" migrants who plan to stay forever (bottom right panel) have very little link to rural regions - except when they are not close to other migrants in the city. Results confirm that the signal effect is weaker for them than for those who plan to stay but arrived more recently.

Robustness Checks We summarize here a series of results based on alternative estimations (detailed results available from the authors). First, we have included more migrantspecific variables related to housing conditions, job conditions, family background and social networks in the estimations. Some of these variables have a very significant effect

instance, those with higher beliefs, more ambition and experiencing potentially higher signal effects are also those who may stay longer. Moreover, we cannot preclude that cohort effects play a role. Yet, and despite continuous changes in hukou and migration policy, there is no clear-cut policy events that can be isolated as a main driver behind these results. More precisely, there is no obvious policy that could explain why those who migrated before 2002 (and hence have more than 6 years since migration in our 2008 data) are more susceptible to positive positional concerns toward urban residents. 
Table 5: Relative Income Effects: Sub-groups of Migrants

\begin{tabular}{|c|c|c|c|c|}
\hline Ref. group & $\begin{array}{l}\text { Return some day, } \\
\text { YSM }<=6\end{array}$ & $\begin{array}{c}\text { Return some day, } \\
\text { YSM >6 }\end{array}$ & $\begin{array}{l}\text { Stay forever, YSM } \\
<=6\end{array}$ & $\begin{array}{l}\text { Stay forever, } \\
\text { YSM }>6\end{array}$ \\
\hline Rural, same home province & $\begin{array}{r}0.016 \\
(0.235)\end{array}$ & $\begin{array}{l}-0.379 \\
(0.266)\end{array}$ & $\begin{array}{l}-0.481 * * \\
(0.216)\end{array}$ & $\begin{array}{l}-0.321 * \\
(0.199)\end{array}$ \\
\hline Migrants, same city \& YSM & $\begin{array}{l}-0.343 \\
(0.237)\end{array}$ & $\begin{array}{l}-0.203 \\
(0.261)\end{array}$ & $\begin{array}{l}-0.713 * * * \\
(0.234)\end{array}$ & $\begin{array}{l}-0.426 * * \\
(0.205)\end{array}$ \\
\hline Migrants, same city, YSM \& origin & $\begin{array}{l}-0.201 \\
(0.150)\end{array}$ & $\begin{array}{l}-0.204 \\
(0.148)\end{array}$ & $\begin{array}{l}-0.093 \\
(0.163)\end{array}$ & $\begin{array}{l}-0.057 \\
(0.128)\end{array}$ \\
\hline Urban, same city \& age group & $\begin{array}{r}0.068 \\
(0.090)\end{array}$ & $\begin{array}{r}0.157 \\
(0.119)\end{array}$ & $\begin{array}{l}0.376 * * * \\
(0.080)\end{array}$ & $\begin{array}{l}0.213 \text { ** } \\
(0.089)\end{array}$ \\
\hline \# obs. for rural ref. group @ & 858 & 716 & 987 & 1191 \\
\hline \# obs. all other cases & 1163 & 918 & 1270 & 1527 \\
\hline
\end{tabular}

on SWB. The absence of family, and one's children in particular, is highly negatively associated with migrants well-being, as well as poor financial conditions (proxied by the question on whether a migrant is looking for a new job to improve his earnings). Large social networks improve SWB very significantly. More importantly, the addition of these variables does not change our results. The status effect vis-à-vis rural workers is still significant (magnitude of -.27 versus -.32 when these variables are ignored). The signal effect toward urban income is barely unchanged (.17 versus .20) and so is the status effect from other migrants $(-.38$ versus -.42$)$ or migrants of same origin $(-.14$ versus -.13$)$.

In another series of checks we introduce different reference groups simultaneously. Based on previous results, our favored specification consists of the following groups: rural workers of the same province, urban workers in the same city and same age group, migrants in the same city, similar duration of stay (and possibly same province of origin). The main results are confirmed in this case and show that several reference points matter. ${ }^{24}$ In particular, the signal effect from urban income and the status effect from rural workers are both highly significant. An exception, however, is the relative income effect from migrants: it is not significant when included in the same regression together with the rural reference group. The income levels of these two groups are similar, but we are asking too much from the data when trying to identify these different effects. The status effect from other migrants - and no effect for migrants of same origin - appears, however,

\footnotetext{
${ }^{24}$ Interestingly, results show that other migrants generate status effects, while migrants of same origin do not (the latter effect is not significant in simultaneous estimations).
} 
when used together with the urban reference group alone.

We also recognize that the previously defined groups are endogenous to a migrant worker's own income level. We have therefore redone estimations while excluding it, in the spirit of a jackknife estimation. Results hardly change.

Finally, we have not yet mentioned the selection issue, namely the fact that migrants are self-selected people in quest of a better life. There are two main related aspects to these questions: (i) migrants may simply be different from the overall population, (ii) these differences may affect the positional preferences of the migrants. On the first issue, we have presented some descriptive statistics showing that migrants are indeed different in terms of observed attributes (younger, more often single, etc.). It would be possible to control for these observables, yet one may argue that the selection issue hinges on unobserved heterogeneity: migrants are in general suspected to be more ambitious (or more desperate) than average. On the second issue, it is possible that migrants move not only to improve absolute income levels but precisely to change their relative income position or status in their source region (see Stark and Taylor, 1991). Hence, they could be selected with respect to their degree of relative concerns and in the worst case, we overestimate the intensity of relative concerns. More generally, we argue that selection issues may be less of an issue here - at least compared to situation where a small fringe of the population is examined. We have recalled the incredible magnitude of Chinese internal migration: the current stock of rural-to-urban migrant workers in China represents around $18 \%$ of the Chinese population. This group of around 230 million people (about the size of the population of Germany, France and the UK combined) is certainly worth studying, and selection biases appear to be a second order problem in this context.

\section{Conclusion}

Studying the determinants of rural-to-urban migrants' welfare in China is certainly worth undertaking given the size of this population. The present study and Knight and Gunatilaka (2010a) are the first attempts to do so using subjective well-being information. Equally interesting is the fact that this group is potentially confronted to different comparison groups, and hence offers a unique chance to statistically test the relative concerns attached to these various groups. This is the task assigned to this paper. ${ }^{25}$ Exploiting

\footnotetext{
${ }^{25}$ Arguably, the relatively indirect nature of the evidence provided in this type of study necessitates some support from more direct evidence on whom people compare themselves to (see Clark and Senik, 2010). Also, panel data can help to understand better the dynamics of reference group formation, possible switches in reference groups and the different time effects implicit in our results (age effect, duration of
} 
a unique dataset on rural, migrant and urban households, we find very suggestive evidence that several of these groups matter, i.e., their income affects migrant well-being significantly, and do so in different ways. While the economic success of other migrants in urban areas and rural workers in source regions depresses migrant welfare due to a well-understood 'status' effect, envy and competition conflict with possible altruistic and reciprocal attitudes among migrants of the same origin. Migrant well-being is also positively influenced by local urban income. We rule out altruism and externalities as possible explanations for this result and gather substantial evidence that this can be related to a 'signal' effect. Migrants, and especially young ones who aspire to settle and make a career in urban regions, treat urban workers' income as a signal for their future prospects. Results show substantial heterogeneity among migrants: the relative importance of the different reference groups varies significantly depending on past and expected duration of stay, on work conditions and on interaction with the environment and in particular with the local community of migrants from the same origin.

We believe that these results are important and should encourage more work on migrants' positional concerns in China. Indeed, it is crucial to isolate the different types of social interactions affecting migrants (and urban natives), as they may have very different economic, social and policy implications. If comparison effects (status) dominate, the "social harmony" seeked by the Chinese government in the recent years possibly requires more redistributive policies in order to reduce inequalities in urban regions - and not only policies that bridge the gap between urban and rural China (see Knight and Gunatilaka, 2010b). This is probably less of a priority if migrants are mainly influenced by the prospect of mobility. In fact, while rapid rural-urban migration has given rise to various social problems in several developing countries, such issues have not yet arisen in China. This can not longer be put on account of restricted migration, given the magnitude of the phenomenon.

Yet, migrants form an heterogeneous population - temporary migrants or those who perceive they do not belong to a prosperous urban world while living in miserable conditions in Chinese suburbs could be those fomenting unrest. Wise policy measures may aim at improving their living conditions in any case. Positional concerns also relate directly to the political economy literature, whereby expected future income and beliefs in social mobility influence inequality aversion and voting behavior (see Benabou and Ok, 2001). If migrants were allowed to vote in local elections, their political views may completely differ from those of urban natives and would affect the political outcome. Migrants may also "vote with their feet" - more needs to be done to understand the link between aspiration,

stay in urban regions, cohort effects and specific policy events in migration history). We keep this for future research. 
city attractiveness and distance from home regions. Finally, how migrants' well-being vary with relative income may also provide new measures of assimilation. These are only a few examples of how positional concerns may crucially influence the Chinese economy and society in the future.

\section{References}

[1] Akay, A. and Martinsson, P. (2011): "Does Relative Income Matter for the Very Poor? Evidence from Rural Ethiopia", Economics Letters, 110(3), 213-215.

[2] Alpizar, F., F. Carlsson and O. Johansson-Stenman (2005): "How Much Do We Care about Absolute versus Relative Income and Consumption?", Journal of Economic Behavior and Organization 56(3), 405-421.

[3] Appleton, S. and L. Song (2009): "Life Satisfaction in Urban China: Components and Determinants", World Development, 36(11), 2325-2340.

[4] Argyle, M. (1999): "Causes and Correlates of Happiness", In Well-Being: The Foundations of Hedonic Psychology, D. Kahneman, E. Diener, and N. Schwarz (eds.), New York: Russel Sage Foundation, pp. 353-373..

[5] Bai, N. and H. Song (2002): "Return or Stay in Urban Area?" Beijing: China Financial \& Economic Publishing House.

[6] Benabou, R. and E. Ok (2001): "Social Mobility and the Demand for Redistribution: The POUM Hypothesis," Quarterly Journal of Economics, 116(2), 447-487.

[7] Benz, M. and B. Frey (2008): "Being Independent is a Great Thing: Subjective Evaluations of Self-Employment and Hierarchy," Economica, 75(298), 362-383.

[8] Blanchflower, D. and A. Oswald (2004): "Well-Being Over Time in Britain and the USA", Journal of Public Economics. 88(7-8), 1359-1386.

[9] Bookwalter, J. and D. R. Dalenberg (2010): "Relative to What or Whom? The Importance of Norms and Relative Standing to Well-Being in South Africa," World Development, 38(3), 345-355.

[10] Brandt, L. and C. Holz (2006): "Spatial Price Differences in China: Estimates and Implications", Economic Development and Cultural Change, 55, 43-86.

[11] Cai, F., A. Park and Y. Zhao (2008): "The Chinese labor market in the reform era", in L. Brandt, \& T. Rawsi (Eds.), China's Great Economic Transformation. New York and Cambridge: Cambridge University Press. 
[12] Carlsson, F., O. Johansson-Stenman and P. Martinsson (2007a): "Do You Enjoy Having More than Others? Survey Evidence of Positional Goods", Economica 74(296), 586-598.

[13] Carlsson, F., P. Nam, M. Linde-Rahr and P. Martinsson (2007b): "Are Vietnamese Farmers Concerned with Their Relative Position in Society?", Journal of Development Studies 43(7): 1177-1188.

[14] Clark, A., P. Frijters and M. Shields (2008): "Relative income, happiness and utility: An explanation of the Easterlin Paradox and other puzzles", Journal of Economic Literature, 46(1), 95-144.

[15] Clark, A. and A. Oswald (1994): "Unhappiness and Unemployment", Economic Journal, 104(424), 648-659.

[16] Clark, A. and A. Oswald (1996): "Satisfaction and Comparison Income", Journal of Public Economics, 61(3), 359-381.

[17] Clark, A. and C. Senik (2009): "Who Compares to Whom? The Anatomy of Income Comparisons in Europe", Economic Journal, 120(544), 573-594.

[18] Dolan, P., T. Peasgood and M. White (2008): "Do We Really Know What Makes Us Happy?A Review of the Economic Literature on the Factors Associated with Subjective Well-Being," Journal of Economic Psychology, 29(1), 94-122.

[19] Duesenberry, J. (1949): Income, Saving and the Theory of Consumer Behavior. Cambridge, MA: Harvard University Press.

[20] Easterlin, R. (1995): "Will Raising the Incomes of All Increase the Happiness of All?", Journal of Economic Behavior and Organization, 27(1), 35-47.

[21] Easterlin, R. (2010): Happiness, Growth, and the Life Cycle, edited by H. Hinte and K.F. Zimmerman (eds.), Oxford: Oxford Economic Press.

[22] Ferrer-i-Carbonell A. (2005): "Income and Well-Being: An Empirical Analysis of the Comparison Income Effect", Journal of Public Economics, 89(5-6): 997-1019.

[23] Ferrer-i-Carbonell, A. and P. Frijters (2004): "How Important is Methodology for the Estimates of the Determinants of Happiness?", Economic Journal, 114(497), $641-659$.

[24] Frey, B. and A. Stutzer (2002): "What Can Economists Learn from Happiness Research?", Journal of Economic Literature 40(2), 402-435.

[25] Fuentes, N. and M. Rojas (2000): "Economic Theory and Subjective Well-Being: Mexico", Social Indicators Research, 53(3), 289-314. 
[26] Gao, W. and R. Smyth (2010): "Job Satisfaction and Relative income in Economic Transition: Status or Signal? The Case of Urban China". China Economic Review, 21(3), 442-455

[27] Glenn, N. and C. Weaver (1979): "A Multivariate, Multisurvey Study of Marital Happiness", Journal of Marriage and the Family. 40(2), 269-282.

[28] Graham, C. (2005): "Insights on Development from the Economics of Happiness", World Bank Research Observer, 20(2), 201-232.

[29] Graham, C. and S. Pettinato (2002): "Frustrated Achievers: Winners, Losers and Subjective Well-Being in New Market Economies", Journal of Development Studies, 38(4), 100-140.

[30] Gustaffson, B., S. Li and T. Sicular (2008): Inequality and Public Policy in China, New York and Cambridge: Cambridge University Press.

[31] Helliwell, J. (2003): "How's life? Combining Individual and National Variables to Explain Subjective Well-Being", Economic Modelling, 20(2), 331-360.

[32] Hirschman, A. with M. Rothschild (1973): "The changing tolerance for income inequality in the course of economic development", Quarterly Journal of Economics, $87(4), 544-565$.

[33] Johansson-Stenman, O., F. Carlsson and D. Daruvala. (2002): "Measuring Future Grandparents' Preferences for Equality and Relative Standing", Economic Journal, 112(479), 362-383.

[34] Kahneman, D. and R. Sugden. (2005): "Experienced Utility as a Standard of Policy Evaluation," Environmental and Resource Economics, 32(1), 161-181.

[35] Kingdon, G. and J. Knight (2006): "Subjective Well-Being Poverty Versus Income Poverty and Capabilities Poverty?", Journal of Development Studies, 42(7), $1199-1224$.

[36] Kingdon, G. and J. Knight (2007): "Community, Comparisons and Subjective WellBeing in a Divided Society", Journal of Economic Behavior and Organization, 64(1), 69-90.

[37] Knight, J., L. Song and R. Gunatilaka (2009): "The Determinants of Subjective Well-Being in Rural China", China Economic Review, 20(2), 635-649.

[38] Knight, J. and R. Gunatilaka (2010a): "Great Expectations? The Subjective WellBeing of Rural-Urban Migrants in China", World Development, 38(1), 113-124.

[39] Knight, J. and R. Gunatilaka (2010b): "The Rural-Urban Divide in China: Income But Not Happiness?", Journal of Development Studies, 10(28), 471-493. 
[40] Knight, J. and L. Song (1999): "The rural-urban divide. Economic disparities and interactions in China", Oxford: Oxford University Press.

[41] Luttmer, E. (2005): "Neighbors as Negatives: Relative Earnings and Well-Being", Quarterly Journal of Economics, 120(3): 963-1020.

[42] McBride, M. (2001): "Relative-Income Effects on Subjective Well-Being in the CrossSection", Journal of Economic Behavior and Organization, 45(3), 251-278.

[43] Meng, X., C. Manning, Li and T. Effendi (2010, eds.): The Great Migration: RuralUrban Migration in China and Indonesia, Cheltenham: Edward Elgar Publishing Ltd.

[44] Meng, X. and D. Zhang (2010): "Labour Market Impact of Large Scale Internal Migration on Chinese Urban 'Native' Workers", IZA DP No. 5288

[45] Pérez-Asenjo, E. (2010): "If Happiness is Relative, Against Whom Do We Compare Ourselves? Implications for Labour Supply", forthcoming in Journal of Population Economics.

[46] Qu, Z. and Z. Zhao (2011): "Evolution of the Chinese Rural-Urban Migrant Labor Market from 2002 to 2007", IZA Discussion Paper, No. 5421.

[47] Ravallion, M., M. Lokshin (2000): "Who Wants to Redistribute? The Tunnel Effect in 1990s Russia", Journal of Public Economic, 76(81), 87-104.

[48] RCEMS (2009), Report on Public Service Indices of Chinese City, Research Center for Economic and Management Services, Shanghai: Shanghai University Press

[49] Senik, C. (2004): "When Information Dominates Comparison: A Panel Data Analysis Using Russian Subjective Data", Journal of Public Economics, 88(9-10), 2099-2123.

[50] Senik, C. (2008): "Ambition and Jealousy. Income Interactions in the "Old" Europe versus the "New" Europe and the United States", Economica, 75(299), 495-513.

[51] Senik, C. (2009): "Direct Evidence on Income Comparisons and Their Welfare Effects", Journal of Economic Behavior and Organization, 72(1), 408-424.

[52] Solnick, S., and D. Hemenway (1998): "Is More Always Better? A Survey on Positional Concerns", Journal of Economic Behavior \&f Organization 37: 373-383.

[53] Stark, O. and J. Taylor (1991): "Migration Incentives, Migration Types: The Role of Relative Deprivation", Economic Journal, 101, 1163-1178.

[54] van Praag, B., P. Frijters and A. Ferrer-i-Carbonell (2003): "The Anatomy of Subjective Well-Being", Journal of Economic Behavior and Organization ,51(1), 29-49. 
[55] Veall, M. R and K. F. Zimmermann (1996): "Pseudo-R2 Measures for Some Common Limited Dependent Variable Models", Journal of Economic Surveys, 10(3), 24159

[56] Veblen, T. (1899): The Theory of the Leisure Class. Digireads.com.

[57] Winkelmann, L. and R. Winkelmann (1998): "Why Are the Unemployed so Unhappy? Evidence from Panel Data", Economica, 65(257), 1-16. 


\section{A Appendix A: GHQ-12 Measure of Well-Being}

1- When you are doing something, do you find that

1)Can concentrate 2)Attention occasionally diverted 3)Attention sometimes diverted

4) Attention frequently diverted, cannot concentrate

2- Do you often lose sleep over worry?

1)Not at all 2) Occasionally 3)Fairly often 4)Very often

3- Can you play useful part in things?

1)Always can 2)Can play some positive roles 3) Can play positive roles poorly 4)Cannot play a positive role

4- Are you capable of making decisions?

1)Always have own opinions 2) Sometimes have own opinions 3)Do not have many own opinions

4)Do not have any personal opinion at all

5- Are you constantly under strain?

1)Never 2)Sometimes 3)Fairly often 4) Very often

6- Do you feel you couldn't overcome difficulties?

1)Never 2) Sometimes 3)Fairly often4)Very often

7- Are you able to enjoy day-to-day activities?

1)Very interesting 2) Fairly interesting3)Not very interesting 4)Not interesting at all

8-Are you able to face problems?

1)Never 2) Seldom 3) Sometimes 4) Always

9- Do you feel depressed?

1)Not at all 2) A little bit 3)Fairly seriously 4)Very seriously

10- Do you always lack confidence?

1)Not at all 2) A little bit 3)Fairly seriously 4)Very seriously

11- Do you often think that you have no value?

1)Not at all 2) A little bit 3)Fairly seriously 4)Very seriously

12- Are you happy when you consider each aspect of your life?

1)Very happy 2)Fairly happy 3)Not very happy 4)Not happy at all 


\title{
B Appendix B: Additional Tables
}

\author{
Table B.1: Descriptive Statistics
}

\begin{tabular}{|c|c|c|c|c|c|c|c|c|c|c|c|c|}
\hline & \multicolumn{4}{|c|}{ Rural } & \multicolumn{5}{|c|}{ 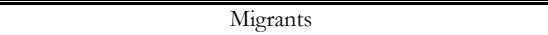 } & \multicolumn{3}{|c|}{ Urban } \\
\hline & All & $\mathrm{SWB}<4$ & $\mathrm{SWB}=4,5$ & $\mathrm{SWB}>5$ & All & SWB $<4$ & $\mathrm{SWB}=4,5$ & $\mathrm{SWB}>5$ & All & $\mathrm{SWB}<4$ & $\mathrm{SWB}=4,5$ & $\mathrm{SWB}>5$ \\
\hline Salary worker $(0 / 1)$ & $\begin{array}{c}0.73 \\
(0.44)\end{array}$ & $\begin{array}{c}0.74 \\
(0.44)\end{array}$ & $\begin{array}{c}0.75 \\
(0.43)\end{array}$ & $\begin{array}{c}0.72 \\
(0.45)\end{array}$ & $\begin{array}{c}0.80 \\
(0.40)\end{array}$ & $\begin{array}{c}0.81 \\
(0.39)\end{array}$ & $\begin{array}{c}0.80 \\
(0.40)\end{array}$ & $\begin{array}{c}0.79 \\
(0.41)\end{array}$ & $\begin{array}{c}0.89 \\
(0.31)\end{array}$ & $\begin{array}{c}0.86 \\
(0.34)\end{array}$ & $\begin{array}{c}0.91 \\
(0.29)\end{array}$ & $\begin{array}{c}0.89 \\
(0.32)\end{array}$ \\
\hline Log hours of work & $\begin{array}{c}3.8 \\
(0.6)\end{array}$ & $\begin{array}{c}3.8 \\
(0.6)\end{array}$ & $\begin{array}{c}3.8 \\
(0.6)\end{array}$ & $\begin{array}{c}3.8 \\
(0.6)\end{array}$ & $\begin{array}{c}4.1 \\
(0.2)\end{array}$ & $\begin{array}{c}4.1 \\
(0.2)\end{array}$ & $\begin{array}{c}4.1 \\
(0.2)\end{array}$ & $\begin{array}{l}4.1 \\
(0.2)\end{array}$ & $\begin{array}{c}3.7 \\
(0.4)\end{array}$ & $\begin{array}{c}3.8 \\
(0.4)\end{array}$ & $\begin{array}{c}3.7 \\
(0.4)\end{array}$ & $\begin{array}{c}3.7 \\
(0.3)\end{array}$ \\
\hline Age & $\begin{array}{l}46.7 \\
(8.5)\end{array}$ & $\begin{array}{l}47.7 \\
(8.5)\end{array}$ & $\begin{array}{l}46.7 \\
(8.4)\end{array}$ & $\begin{array}{l}46.4 \\
(8.7)\end{array}$ & $\begin{array}{c}30.7 \\
(10.2)\end{array}$ & $\begin{array}{c}30.5 \\
(10.7)\end{array}$ & $\begin{array}{c}30.7 \\
(10.1)\end{array}$ & $\begin{array}{c}31.0 \\
(10.0)\end{array}$ & $\begin{array}{l}42.5 \\
(8.4)\end{array}$ & $\begin{array}{l}43.3 \\
(8.4)\end{array}$ & $\begin{array}{l}42.5 \\
(8.4)\end{array}$ & $\begin{array}{l}42.2 \\
(8.5)\end{array}$ \\
\hline Female $(0 / 1)$ & $\begin{array}{c}0.03 \\
(0.16)\end{array}$ & $\begin{array}{c}0.05 \\
(0.22)\end{array}$ & $\begin{array}{c}0.03 \\
(0.16)\end{array}$ & $\begin{array}{c}0.02 \\
(0.15)\end{array}$ & $\begin{array}{c}0.31 \\
(0.46)\end{array}$ & $\begin{array}{c}0.38 \\
(0.48)\end{array}$ & $\begin{array}{c}0.31 \\
(0.46)\end{array}$ & $\begin{array}{c}0.26 \\
(0.44)\end{array}$ & $\begin{array}{l}0.34 \\
(0.47)\end{array}$ & $\begin{array}{c}0.36 \\
(0.48)\end{array}$ & $\begin{array}{c}0.34 \\
(0.47)\end{array}$ & $\begin{array}{c}0.32 \\
(0.47)\end{array}$ \\
\hline Married $(0 / 1)$ & $\begin{array}{c}0.98 \\
(0.15)\end{array}$ & $\begin{array}{c}0.94 \\
(0.23)\end{array}$ & $\begin{array}{c}0.98 \\
(0.14)\end{array}$ & $\begin{array}{c}0.99 \\
(0.11)\end{array}$ & $\begin{array}{c}0.54 \\
(0.50)\end{array}$ & $\begin{array}{c}0.48 \\
(0.50)\end{array}$ & $\begin{array}{c}0.54 \\
(0.50)\end{array}$ & $\begin{array}{c}0.57 \\
(0.49)\end{array}$ & $\begin{array}{c}0.93 \\
(0.26)\end{array}$ & $\begin{array}{c}0.88 \\
(0.33)\end{array}$ & $\begin{array}{c}0.93 \\
(0.26)\end{array}$ & $\begin{array}{c}0.95 \\
(0.21)\end{array}$ \\
\hline 0 child $(0 / 1)$ & $\begin{array}{c}0.02 \\
(0.16)\end{array}$ & $\begin{array}{c}0.02 \\
(0.14)\end{array}$ & $\begin{array}{c}0.03 \\
(0.16)\end{array}$ & $\begin{array}{c}0.02 \\
(0.15)\end{array}$ & $\begin{array}{c}0.48 \\
(0.50)\end{array}$ & $\begin{array}{c}0.53 \\
(0.50)\end{array}$ & $\begin{array}{c}0.48 \\
(0.50)\end{array}$ & $\begin{array}{c}0.46 \\
(0.50)\end{array}$ & $\begin{array}{c}0.08 \\
(0.28)\end{array}$ & $\begin{array}{c}0.08 \\
(0.27)\end{array}$ & $\begin{array}{c}0.08 \\
(0.27)\end{array}$ & $\begin{array}{c}0.09 \\
(0.29)\end{array}$ \\
\hline 1 child $(0 / 1)$ & $\begin{array}{c}0.37 \\
(0.48)\end{array}$ & $\begin{array}{c}0.31 \\
(0.46)\end{array}$ & $\begin{array}{c}0.38 \\
(0.49)\end{array}$ & $\begin{array}{c}0.39 \\
(0.49)\end{array}$ & $\begin{array}{c}0.31 \\
(0.46)\end{array}$ & $\begin{array}{c}0.28 \\
(0.45)\end{array}$ & $\begin{array}{c}0.31 \\
(0.46)\end{array}$ & $\begin{array}{c}0.33 \\
(0.47)\end{array}$ & $\begin{array}{l}0.84 \\
(0.37)\end{array}$ & $\begin{array}{c}0.86 \\
(0.35)\end{array}$ & $\begin{array}{c}0.84 \\
(0.37)\end{array}$ & $\begin{array}{c}0.83 \\
(0.38)\end{array}$ \\
\hline 2 children $(0 / 1)$ & $\begin{array}{c}0.42 \\
(0.49)\end{array}$ & $\begin{array}{c}0.44 \\
(0.50)\end{array}$ & $\begin{array}{c}0.41 \\
(0.49)\end{array}$ & $\begin{array}{c}0.42 \\
(0.49)\end{array}$ & $\begin{array}{c}0.17 \\
(0.37)\end{array}$ & $\begin{array}{c}0.14 \\
(0.35)\end{array}$ & $\begin{array}{c}0.18 \\
(0.38)\end{array}$ & $\begin{array}{c}0.17 \\
(0.37)\end{array}$ & $\begin{array}{l}0.07 \\
(0.25)\end{array}$ & $\begin{array}{c}0.06 \\
(0.23)\end{array}$ & $\begin{array}{c}0.07 \\
(0.25)\end{array}$ & $\begin{array}{c}0.08 \\
(0.27)\end{array}$ \\
\hline 3 children $+(0 / 1)$ & $\begin{array}{c}0.18 \\
(0.39)\end{array}$ & $\begin{array}{c}0.24 \\
(0.43)\end{array}$ & $\begin{array}{c}0.18 \\
(0.38)\end{array}$ & $\begin{array}{c}0.16 \\
(0.37)\end{array}$ & $\begin{array}{c}0.03 \\
(0.18)\end{array}$ & $\begin{array}{c}0.04 \\
(0.19)\end{array}$ & $\begin{array}{c}0.03 \\
(0.17)\end{array}$ & $\begin{array}{c}0.04 \\
(0.19)\end{array}$ & $\begin{array}{c}0.01 \\
(0.09)\end{array}$ & $\begin{array}{c}0.01 \\
(0.09)\end{array}$ & $\begin{array}{c}0.01 \\
(0.11)\end{array}$ & $\begin{array}{c}0.00 \\
(0.06)\end{array}$ \\
\hline Years of schooling & $\begin{array}{c}8.2 \\
(2.5)\end{array}$ & $\begin{array}{l}7.8 \\
(2.8)\end{array}$ & $\begin{array}{l}8.1 \\
(2.4)\end{array}$ & $\begin{array}{l}8.5 \\
(2.4)\end{array}$ & $\begin{array}{c}9.4 \\
(2.5)\end{array}$ & $\begin{array}{l}9.0 \\
(2.4)\end{array}$ & $\begin{array}{l}9.3 \\
(2.5)\end{array}$ & $\begin{array}{l}9.6 \\
(2.5)\end{array}$ & $\begin{array}{l}11.8 \\
(2.8)\end{array}$ & $\begin{array}{l}11.4 \\
(2.9)\end{array}$ & $\begin{array}{l}11.6 \\
(2.7)\end{array}$ & $\begin{array}{l}12.1 \\
(2.9)\end{array}$ \\
\hline Abs. income & $\begin{array}{l}1369 \\
(956)\end{array}$ & $\begin{array}{l}1153 \\
(691)\end{array}$ & $\begin{array}{l}1317 \\
(907)\end{array}$ & $\begin{array}{c}1485 \\
(1052)\end{array}$ & $\begin{array}{c}1625 \\
(1087)\end{array}$ & $\begin{array}{l}1495 \\
(908)\end{array}$ & $\begin{array}{c}1596 \\
(1055)\end{array}$ & $\begin{array}{c}1732 \\
(1200)\end{array}$ & $\begin{array}{c}2376 \\
(1678)\end{array}$ & $\begin{array}{c}2067 \\
(1542)\end{array}$ & $\begin{array}{c}2319 \\
(1662)\end{array}$ & $\begin{array}{c}2593 \\
(1735)\end{array}$ \\
\hline Mean SWB & $\begin{array}{c}5.1 \\
(1.5)\end{array}$ & $\begin{array}{l}2.6 \\
(0.7)\end{array}$ & $\begin{array}{c}4.5 \\
(0.5)\end{array}$ & $\begin{array}{c}6.5 \\
(0.5)\end{array}$ & $\begin{array}{c}4.8 \\
(1.5)\end{array}$ & $\begin{array}{c}2.5 \\
(0.7)\end{array}$ & $\begin{array}{c}4.5 \\
(0.5)\end{array}$ & $\begin{array}{c}6.4 \\
(0.5)\end{array}$ & $\begin{array}{c}4.9 \\
(1.5)\end{array}$ & $\begin{array}{c}2.6 \\
(0.7)\end{array}$ & $\begin{array}{c}4.5 \\
(0.5)\end{array}$ & $\begin{array}{l}6.4 \\
(0.5)\end{array}$ \\
\hline Mean health score $(1-5)$ & $\begin{array}{c}4.1 \\
(0.7)\end{array}$ & $\begin{array}{c}3.8 \\
(0.8)\end{array}$ & $\begin{array}{c}4.0 \\
(0.7)\end{array}$ & $\begin{array}{l}4.3 \\
(0.7)\end{array}$ & $\begin{array}{c}4.3 \\
(0.7)\end{array}$ & $\begin{array}{c}3.9 \\
(0.8)\end{array}$ & $\begin{array}{l}4.2 \\
(0.7)\end{array}$ & $\begin{array}{l}4.5 \\
(0.6)\end{array}$ & $\begin{array}{c}3.9 \\
(0.7)\end{array}$ & $\begin{array}{c}3.5 \\
(0.7)\end{array}$ & $\begin{array}{c}3.8 \\
(0.7)\end{array}$ & $\begin{array}{l}4.1 \\
(0.7)\end{array}$ \\
\hline Unempl. insurance $(0 / 1)$ & $\begin{array}{c}0.08 \\
(0.28)\end{array}$ & $\begin{array}{c}0.06 \\
(0.23)\end{array}$ & $\begin{array}{c}0.07 \\
(0.25)\end{array}$ & $\begin{array}{c}0.10 \\
(0.31)\end{array}$ & $\begin{array}{c}0.12 \\
(0.33)\end{array}$ & $\begin{array}{c}0.09 \\
(0.29)\end{array}$ & $\begin{array}{c}0.11 \\
(0.32)\end{array}$ & $\begin{array}{c}0.16 \\
(0.36)\end{array}$ & $\begin{array}{c}0.62 \\
(0.49)\end{array}$ & $\begin{array}{c}0.57 \\
(0.50)\end{array}$ & $\begin{array}{c}0.63 \\
(0.48)\end{array}$ & $\begin{array}{c}0.63 \\
(0.48)\end{array}$ \\
\hline Pension insurance $(0 / 1)$ & $\begin{array}{c}0.25 \\
(0.44)\end{array}$ & $\begin{array}{c}0.13 \\
(0.34)\end{array}$ & $\begin{array}{c}0.25 \\
(0.43)\end{array}$ & $\begin{array}{c}0.30 \\
(0.46)\end{array}$ & $\begin{array}{c}0.20 \\
(0.40)\end{array}$ & $\begin{array}{c}0.17 \\
(0.37)\end{array}$ & $\begin{array}{c}0.19 \\
(0.40)\end{array}$ & $\begin{array}{c}0.23 \\
(0.42)\end{array}$ & $\begin{array}{c}0.82 \\
(0.39\end{array}$ & $\begin{array}{c}0.77 \\
(0.42)\end{array}$ & $\begin{array}{c}0.83 \\
(0.37)\end{array}$ & $\begin{array}{c}0.82 \\
(0.38)\end{array}$ \\
\hline Injury insurance $(0 / 1)$ & $\begin{array}{c}0.16 \\
(0.36)\end{array}$ & $\begin{array}{c}0.09 \\
(0.28)\end{array}$ & $\begin{array}{c}0.15 \\
(0.36)\end{array}$ & $\begin{array}{c}0.18 \\
(0.38)\end{array}$ & $\begin{array}{c}0.19 \\
(0.39)\end{array}$ & $\begin{array}{c}0.14 \\
(0.34)\end{array}$ & $\begin{array}{c}0.18 \\
(0.39)\end{array}$ & $\begin{array}{c}0.24 \\
(0.42)\end{array}$ & $\begin{array}{c}0.52 \\
(0.50)\end{array}$ & $\begin{array}{c}0.47 \\
(0.50)\end{array}$ & $\begin{array}{c}0.52 \\
(0.50)\end{array}$ & $\begin{array}{c}0.54 \\
(0.50)\end{array}$ \\
\hline Specific information ab & $t m i g r$ & & & & & & & & & & & \\
\hline Hypoth. rural income & & & & & 682 & 633 & 676 & 714 & & & & \\
\hline Lives with some of his/he & childrer & & & & 0.26 & 0.25 & 0.26 & 0.27 & & & & \\
\hline Lives with his/her spouse & $0 / 1)$ & & & & 0.35 & 0.32 & 0.34 & 0.37 & & & & \\
\hline Lives close to many peop & of same & $\operatorname{gin}(0 / 1)$ & & & 0.50 & 0.48 & 0.49 & 0.53 & & & & \\
\hline Permanent contract $(0 / 1)$ & & & & & 0.10 & 0.09 & 0.09 & 0.11 & & & & \\
\hline Long-term contract $(0 / 1)$ & & & & & 0.32 & 0.25 & 0.31 & 0.36 & & & & \\
\hline Short-term or no contract & & & & & 0.38 & 0.47 & 0.39 & 0.31 & & & & \\
\hline Years since migration & & & & & 8.0 & 7.8 & 8.0 & 8.3 & & & & \\
\hline If policy allow it, would lit & to stay & he city fore & $\operatorname{rer}(0 / 1)$ & & 57.4 & 49.8 & 57.5 & 61.2 & & & & \\
\hline \# observations & 2180 & 321 & 865 & 994 & 4878 & 886 & 2283 & 1709 & 1863 & 372 & 764 & 727 \\
\hline
\end{tabular}


Table B.2: Additional Checks for Urban and Rural Workers

\begin{tabular}{|c|c|c|c|c|c|c|c|}
\hline \multicolumn{4}{|c|}{ Urban sample } & \multicolumn{4}{|c|}{ Rural sample } \\
\hline & $\bar{I}$ & II & III & & $\bar{I}$ & II & III \\
\hline \multicolumn{4}{|c|}{ Ref. group: same district, type as indicated below } & \multicolumn{4}{|c|}{ Ref. group: same province, type as indicated below } \\
\hline AI & $\begin{array}{l}0.170 \text { *** } \\
(0.051)\end{array}$ & $\begin{array}{l}0.156 \text { *** } \\
(0.054)\end{array}$ & $\begin{array}{l}0.184 \text { *** } \\
(0.058)\end{array}$ & AI & $\begin{array}{l}0.117 \text { *** } \\
(0.029)\end{array}$ & $\begin{array}{l}0.118^{* * *} \\
(0.029)\end{array}$ & $\begin{array}{l}0.108 \text { *** } \\
(0.030)\end{array}$ \\
\hline RI: other urban & $\begin{array}{l}-0.387 \text { *** } \\
(0.139)\end{array}$ & & $\begin{array}{l}-0.473 * * * \\
(0.144)\end{array}$ & RI: other rural & $\begin{array}{l}0.402 \text { ** } \\
(0.162)\end{array}$ & & $\begin{array}{l}0.531 \text { *** } \\
(0.199)\end{array}$ \\
\hline RI: migrants & & $\begin{array}{l}-0.145 \\
(0.202)\end{array}$ & $\begin{array}{r}-0.050 \\
(0.205)\end{array}$ & RI: urban & & $\begin{array}{r}0.609 \\
(0.445)\end{array}$ & $\begin{array}{l}-0.112 \\
(0.532)\end{array}$ \\
\hline Pseudo-R2 & 0.041 & 0.040 & 0.042 & Pseudo-R2 & 0.044 & 0.043 & 0.044 \\
\hline \multicolumn{4}{|c|}{ Ref. group: same district and age group, type as indicated below } & \multicolumn{4}{|c|}{ Ref. group: same province and age groups, type as indicated below } \\
\hline AI & $\begin{array}{l}0.164^{* * *} \\
(0.050)\end{array}$ & $\begin{array}{l}0.154 \text { *** } \\
(0.054)\end{array}$ & $\begin{array}{l}0.178 \text { *** } \\
(0.058)\end{array}$ & AI & $\begin{array}{l}0.120 \text { *** } \\
(0.029)\end{array}$ & $\begin{array}{l}0.119 \text { *** } \\
(0.029)\end{array}$ & $\begin{array}{l}0.109 \text { *** } \\
(0.030)\end{array}$ \\
\hline RI: other urban & $\begin{array}{l}-0.212 * \\
(0.111)\end{array}$ & & $\begin{array}{l}-0.310 \text { *** } \\
(0.116)\end{array}$ & RI: other rural & $\begin{array}{c}0.223 * \\
(0.127)\end{array}$ & & $\begin{array}{l}0.375 \text { ** } \\
(0.156)\end{array}$ \\
\hline RI: migrants & & $\begin{array}{r}0.055 \\
(0.140)\end{array}$ & $\begin{array}{r}0.091 \\
(0.140)\end{array}$ & RI: urban & & $\begin{array}{r}0.245 \\
(0.300)\end{array}$ & $\begin{array}{r}-0.135 \\
(0.348)\end{array}$ \\
\hline Pseudo-R2 & 0.040 & 0.040 & 0.041 & Pseudo-R2 & 0.043 & 0.043 & 0.043 \\
\hline \# Observations & 1863 & 1863 & 1863 & \# Observations & 2180 & 2180 & 2180 \\
\hline
\end{tabular}

Notes: AI stands for Absolute Income effect, RI for Relative Income effect. 
Table B.3: Relative Income Effects of Migrants: Additional Results

\begin{tabular}{|c|c|c|c|c|c|c|c|c|c|c|}
\hline Ref.groups@ & \# obs. & Rural & Migrants & $\begin{array}{l}\text { Migrants } \\
\text { same origin }\end{array}$ & Urban & \# obs. & Rural & Migrants & $\begin{array}{l}\text { Migrants } \\
\text { same origin }\end{array}$ & Urban \\
\hline & \multicolumn{5}{|c|}{ Wish to return some day, YSM $<=6$} & \multicolumn{5}{|c|}{ Wish to return some day, YSM $>6$} \\
\hline Baseline & 1163 & $\begin{array}{l}-0.049 \\
(0.234)\end{array}$ & $\begin{array}{l}-0.359 \\
(0.241)\end{array}$ & $\begin{array}{l}-0.190 \\
(0.152)\end{array}$ & $\begin{array}{r}0.070 \\
(0.090)\end{array}$ & 918 & $\begin{array}{l}-0.404 \\
(0.263)\end{array}$ & $\begin{array}{l}-0.108 \\
(0.268)\end{array}$ & $\begin{array}{l}-0.226 \\
(0.150)\end{array}$ & $\begin{array}{r}0.126 \\
(0.120)\end{array}$ \\
\hline Kids/spouse stayed in rural areas & 997 & $\begin{array}{l}-0.202 \\
(0.255)\end{array}$ & $\begin{array}{l}-0.452 * \\
(0.260)\end{array}$ & $\begin{array}{l}-0.280 \\
(0.179)\end{array}$ & $\begin{array}{r}0.117 \\
(0.094)\end{array}$ & 505 & $\begin{array}{l}-0.865 \text { ** } \\
(0.360)\end{array}$ & $\begin{array}{l}-1.029 \text { *** } \\
(0.354)\end{array}$ & $\begin{array}{l}-0.361 * \\
(0.192)\end{array}$ & $\begin{array}{r}0.218 \\
(0.165)\end{array}$ \\
\hline Permanent or long-term contract & 520 & $\begin{array}{l}-0.728 \text { ** } \\
(0.343)\end{array}$ & $\begin{array}{l}-0.985 * * * \\
(0.355)\end{array}$ & $\begin{array}{l}-0.586 \text { ** } \\
(0.247)\end{array}$ & $\begin{array}{l}0.404 \text { *** } \\
(0.140)\end{array}$ & 370 & $\begin{array}{l}-1.645 \text { *** } \\
(0.464)\end{array}$ & $\begin{array}{l}-0.680 \\
(0.429)\end{array}$ & $\begin{array}{l}-0.148 \\
(0.242)\end{array}$ & $\begin{array}{r}0.235 \\
(0.183)\end{array}$ \\
\hline No or temporary contract & 643 & $\begin{array}{c}0.575 * \\
(0.334)\end{array}$ & $\begin{array}{r}0.275 \\
(0.355)\end{array}$ & $\begin{array}{r}0.115 \\
(0.198)\end{array}$ & $\begin{array}{l}-0.168 \\
(0.116)\end{array}$ & 548 & $\begin{array}{r}0.084 \\
(0.346)\end{array}$ & $\begin{array}{l}-0.026 \\
(0.376)\end{array}$ & $\begin{array}{l}-0.303 \\
(0.195)\end{array}$ & $\begin{array}{l}-0.046 \\
(0.169)\end{array}$ \\
\hline Young (age $<=25$ ) & 781 & $\begin{array}{l}-0.088 \\
(0.298)\end{array}$ & $\begin{array}{l}-0.470 \\
(0.301)\end{array}$ & $\begin{array}{l}-0.305 \\
(0.207)\end{array}$ & $\begin{array}{r}0.139 \\
(0.097)\end{array}$ & 88 & $\begin{array}{l}-1.293 \\
(1.240)\end{array}$ & $\begin{array}{l}-0.988 \\
(0.824)\end{array}$ & $\begin{array}{l}-0.484 \\
(0.550)\end{array}$ & $\begin{array}{r}0.218 \\
(0.401)\end{array}$ \\
\hline Older (age $>=40$ ) & 132 & $\begin{array}{l}-0.390 \\
(0.689)\end{array}$ & $\begin{array}{r}0.282 \\
(0.855)\end{array}$ & $\begin{array}{l}-0.314 \\
(0.442)\end{array}$ & $\begin{array}{r}0.231 \\
(0.326)\end{array}$ & 265 & $\begin{array}{l}-0.902 * \\
(0.562)\end{array}$ & $\begin{array}{l}-1.481 \text { ** } \\
(0.726)\end{array}$ & $\begin{array}{l}-0.316 \\
(0.240)\end{array}$ & $\begin{array}{r}0.284 \\
(0.271)\end{array}$ \\
\hline Close to same-origin migrants & 614 & $\begin{array}{r}0.374 \\
(0.315)\end{array}$ & $\begin{array}{r}0.099 \\
(0.328)\end{array}$ & $\begin{array}{l}-0.111 \\
(0.208)\end{array}$ & $\begin{array}{r}0.174 \\
(0.113)\end{array}$ & 519 & $\begin{array}{l}-0.068 \\
(0.387)\end{array}$ & $\begin{array}{r}0.550 \\
(0.353)\end{array}$ & $\begin{array}{r}0.066 \\
(0.221)\end{array}$ & $\begin{array}{r}0.086 \\
(0.147)\end{array}$ \\
\hline Not close to same-origin migrants & 549 & $\begin{array}{l}-0.361 \\
(0.364)\end{array}$ & $\begin{array}{l}-0.873 \text { ** } \\
(0.374)\end{array}$ & $\begin{array}{l}-0.200 \\
(0.229)\end{array}$ & $\begin{array}{l}-0.125 \\
(0.154)\end{array}$ & 399 & $\begin{array}{l}-0.677 * \\
(0.415)\end{array}$ & $\begin{array}{l}-0.993 \text { ** } \\
(0.434)\end{array}$ & $\begin{array}{l}-0.413 \text { ** } \\
(0.207)\end{array}$ & $\begin{array}{r}0.195 \\
(0.216)\end{array}$ \\
\hline Several migration experiences & 260 & $\begin{array}{c}1.088 * \\
(0.579)\end{array}$ & $\begin{array}{c}0.935 * \\
(0.548)\end{array}$ & $\begin{array}{r}0.461 \\
(0.333)\end{array}$ & $\begin{array}{r}0.128 \\
(0.243)\end{array}$ & 217 & $\begin{array}{r}0.643 \\
(0.603)\end{array}$ & $\begin{array}{l}-0.041 \\
(0.558)\end{array}$ & $\begin{array}{l}-0.264 \\
(0.305)\end{array}$ & $\begin{array}{r}0.333 \\
(0.258)\end{array}$ \\
\hline First migration experience & 405 & $\begin{array}{r}0.150 \\
(0.440)\end{array}$ & $\begin{array}{l}-0.778 * \\
(0.411)\end{array}$ & $\begin{array}{l}-0.391 \\
(0.247)\end{array}$ & $\begin{array}{l}-0.011 \\
(0.170)\end{array}$ & 582 & $\begin{array}{l}-0.394 \\
(0.330)\end{array}$ & $\begin{array}{r}-0.304 \\
(0.350)\end{array}$ & $\begin{array}{l}-0.402 \text { ** } \\
(0.179)\end{array}$ & $\begin{array}{r}0.186 \\
(0.153)\end{array}$ \\
\hline & \multicolumn{5}{|c|}{ Wish to stay forever, $Y S M<=6$} & \multicolumn{5}{|c|}{ Wish to stay forever, YSM $>6$} \\
\hline Baseline & 1270 & $\begin{array}{l}-0.547 \text { ** } \\
(0.214)\end{array}$ & $\begin{array}{l}-0.678 * * * \\
(0.245)\end{array}$ & $\begin{array}{l}-0.085 \\
(0.167)\end{array}$ & $\begin{array}{l}0.374 \text { *** } \\
(0.080)\end{array}$ & 1527 & $\begin{array}{l}-0.361 * \\
(0.199)\end{array}$ & $\begin{array}{l}-0.483 \text { ** } \\
(0.220)\end{array}$ & $\begin{array}{l}-0.143 \\
(0.139)\end{array}$ & $\begin{array}{l}0.198 \text { ** } \\
(0.090)\end{array}$ \\
\hline Kids/spouse stayed in rural areas & 1009 & $\begin{array}{l}-0.345 \\
(0.237)\end{array}$ & $\begin{array}{l}-0.659 \text { ** } \\
(0.281)\end{array}$ & $\begin{array}{l}-0.376 * \\
(0.213)\end{array}$ & $\begin{array}{l}0.421 \text { *** } \\
(0.087)\end{array}$ & 601 & $\begin{array}{l}-0.037 \\
(0.312)\end{array}$ & $\begin{array}{l}-0.785 \text { ** } \\
(0.330)\end{array}$ & $\begin{array}{l}-0.201 \\
(0.233)\end{array}$ & $\begin{array}{r}0.152 \\
(0.138)\end{array}$ \\
\hline Permanent or long-term contract & 589 & $\begin{array}{l}-0.433 \\
(0.289)\end{array}$ & $\begin{array}{l}-0.761 \text { ** } \\
(0.373)\end{array}$ & $\begin{array}{l}-0.129 \\
(0.306)\end{array}$ & $\begin{array}{l}0.528 \text { *** } \\
(0.126)\end{array}$ & 557 & $\begin{array}{l}-0.257 \\
(0.308)\end{array}$ & $\begin{array}{l}-0.459 \\
(0.357)\end{array}$ & $\begin{array}{r}0.153 \\
(0.196)\end{array}$ & $\begin{array}{r}0.216 \\
(0.159)\end{array}$ \\
\hline No or temporary contract & 681 & $\begin{array}{l}-0.791 \text { ** } \\
(0.326)\end{array}$ & $\begin{array}{l}-0.835 \text { ** } \\
(0.341)\end{array}$ & $\begin{array}{l}-0.054 \\
(0.203)\end{array}$ & $\begin{array}{l}0.243 \text { ** } \\
(0.108)\end{array}$ & 970 & $\begin{array}{l}-0.335 \\
(0.270)\end{array}$ & $\begin{array}{l}-0.404 \\
(0.301)\end{array}$ & $\begin{array}{l}-0.307 \\
(0.192)\end{array}$ & $\begin{array}{c}0.198 * \\
(0.112)\end{array}$ \\
\hline Young (age $<=25$ ) & 790 & $\begin{array}{l}-0.464 * \\
(0.273)\end{array}$ & $\begin{array}{l}-0.971 \text { *** } \\
(0.320)\end{array}$ & $\begin{array}{l}-0.381 \\
(0.243)\end{array}$ & $\begin{array}{l}0.447 \text { *** } \\
(0.095)\end{array}$ & 102 & $\begin{array}{l}-0.702 \\
(0.930)\end{array}$ & $\begin{array}{l}-3.526 \text { *** } \\
(1.031)\end{array}$ & $\begin{array}{l}-0.860 \\
(0.644)\end{array}$ & $\begin{array}{r}0.462 \\
(0.311)\end{array}$ \\
\hline Older (age $>=40)$ & 144 & $\begin{array}{l}-0.289 \\
(0.743)\end{array}$ & $\begin{array}{r}0.549 \\
(0.724)\end{array}$ & $\begin{array}{r}0.506 \\
(0.505)\end{array}$ & $\begin{array}{r}0.443 \\
(0.361)\end{array}$ & 473 & $\begin{array}{l}-0.399 \\
(0.338)\end{array}$ & $\begin{array}{r}0.529 \\
(0.474)\end{array}$ & $\begin{array}{r}0.107 \\
(0.273)\end{array}$ & $\begin{array}{r}0.106 \\
(0.204)\end{array}$ \\
\hline Close to same-origin migrants & 565 & $\begin{array}{l}-0.473 \\
(0.352)\end{array}$ & $\begin{array}{l}-0.813 \text { ** } \\
(0.354)\end{array}$ & $\begin{array}{l}-0.247 \\
(0.239)\end{array}$ & $\begin{array}{l}0.510^{* * *} \\
(0.128)\end{array}$ & 752 & $\begin{array}{l}-0.107 \\
(0.303)\end{array}$ & $\begin{array}{l}-0.062 \\
(0.320)\end{array}$ & $\begin{array}{l}-0.176 \\
(0.194)\end{array}$ & $\begin{array}{c}0.241 * \\
(0.135)\end{array}$ \\
\hline Not close to same-origin migrants & 705 & $\begin{array}{l}-0.533 * \\
(0.280)\end{array}$ & $\begin{array}{l}-0.617 \text { * } \\
(0.349)\end{array}$ & $\begin{array}{l}-0.020 \\
(0.242)\end{array}$ & $\begin{array}{l}0.250 \text { ** } \\
(0.105)\end{array}$ & 775 & $\begin{array}{l}-0.459 * \\
(0.282)\end{array}$ & $\begin{array}{l}-0.718 \text { ** } \\
(0.316)\end{array}$ & $\begin{array}{l}-0.110 \\
(0.201)\end{array}$ & $\begin{array}{r}0.153 \\
(0.127)\end{array}$ \\
\hline Several migration experiences & 344 & $\begin{array}{l}-0.518 \\
(0.429)\end{array}$ & $\begin{array}{l}-0.793 * \\
(0.473)\end{array}$ & $\begin{array}{l}-0.402 \\
(0.293)\end{array}$ & $\begin{array}{c}0.243 * \\
(0.147)\end{array}$ & 456 & $\begin{array}{l}-0.799 * * \\
(0.357)\end{array}$ & $\begin{array}{l}-0.466 \\
(0.422)\end{array}$ & $\begin{array}{l}-0.487 \text { * } \\
(0.262)\end{array}$ & $\begin{array}{r}0.190 \\
(0.150)\end{array}$ \\
\hline First migration experience & 388 & $\begin{array}{l}-0.119 \\
(0.477)\end{array}$ & $\begin{array}{l}-1.063 * * \\
(0.443)\end{array}$ & $\begin{array}{l}-0.069 \\
(0.273)\end{array}$ & $\begin{array}{r}0.099 \\
(0.150)\end{array}$ & 757 & $\begin{array}{l}-0.370 \\
(0.323)\end{array}$ & $\begin{array}{l}-0.237 \\
(0.329)\end{array}$ & $\begin{array}{r}0.048 \\
(0.191)\end{array}$ & $\begin{array}{r}0.258 \\
(0.127)\end{array}$ \\
\hline
\end{tabular}

(a) Reference groups are: rural workers of same provinces, urban workers of same city and age group, migrants of same city and YSM, migrants of same origin \& same city and YSM; YSM stands for year-since-migration. 